\title{
Immunopathological mechanisms in dogs with rupture of the cranial cruciate ligament
}

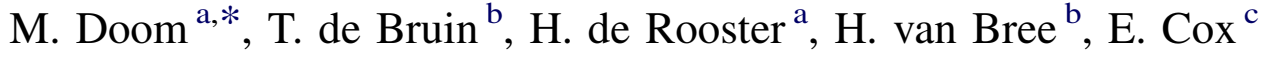 \\ ${ }^{a}$ Department of Small Animal Medicine and Clinical Biology, Faculty of Veterinary Medicine, \\ Ghent University, Salisburylaan 133, 9820 Merelbeke, Belgium \\ ${ }^{\mathrm{b}}$ Department of Diagnostic Imaging of Domestic Animals, Faculty of Veterinary Medicine, \\ Ghent University, Salisburylaan 133, 9820 Merelbeke, Belgium \\ ${ }^{\mathrm{c}}$ Laboratory of Veterinary Immunology, Faculty of Veterinary Medicine, \\ Ghent University, Salisburylaan 133, 9820 Merelbeke, Belgium
}

Received 4 June 2007; received in revised form 6 May 2008; accepted 19 May 2008

\begin{abstract}
The majority of studies on cranial cruciate ligament (CrCL) disease to date have been carried out on dogs that already sustained a $\mathrm{CrCL}$ rupture, which is the end-stage of the disease. Investigations have recently been carried out to study humoral and cellular immunopathological mechanisms in predisposed dogs before clinical rupture of the contralateral CrCL. The cruciate ligaments are mainly composed of collagen type I, and immune responses to collagen have been suggested as a cause of CrCL degradation in dogs. None of these investigations showed evidence that anticollagen type I antibodies alone initiate CrCL damage. However, in predisposed dogs a distinct anticollagen type I antibody gradient was found towards the contralateral stifle joint that eventually sustained a $\mathrm{CrCL}$ rupture, suggesting that there was an inflammatory process present in these joints before detectable joint instability occurred. The importance of cellular reactivity to collagen type I in cruciate disease also remains unclear. Peripheral blood mononuclear cell proliferation to collagen type I was very diverse in dogs with cruciate disease whereas some sham operated dogs and healthy dogs tested positive as well. It is not yet determined whether cellular reactivity to collagen type I exists locally in the stifle joints nor whether this could initiate CrCL degradation.

Inflammatory processes within the stifle joint can alter the composition of the cruciate ligaments. In animal models of immunemediated synovitis, the mechanical strength of the $\mathrm{CrCL}$ is significantly reduced. Immunohistochemical studies on synovial tissues from dogs with rheumatoid arthritis and dogs with cruciate disease revealed that the pathologic features are similar in both joint pathologies and that the differences are mainly quantitative. Joint inflammation induced by biochemical factors such as cytokines has been implied in $\mathrm{CrCL}$ degeneration. In several studies, the levels of pro-inflammatory and $\mathrm{T}$ helper cytokines were measured in dogs that sustained a CrCL rupture, but the exact role of the various cytokines in the pathogenesis of CrCL disease remains inconclusive. More recently, the levels of the cytokines have been investigated over time in predisposed dogs before and after CrCL rupture. IL-8 expression tended to be higher in stifle joints that will rupture their CrCL during the next 6 months than in those that will not, indicating an inflammatory process in these joints before clinical rupture.
\end{abstract}

Abbreviations: ACL, anterior cruciate ligament; bFGF, basic fibroblast growth factor; CD, cluster of differentiation; CIA, collagen-induced arthritis; CrCL, cranial cruciate ligament; CRA, canine rheumatoid arthritis; IFN, interferon; IGF, insuline-like growth factor; IGFBP, insulin-like growth factor binding protein; IL, interleukin; MHC, major histocompatibility complex; MMP, matrix metalloproteinase; OA, osteoarthritis; PDGF, platelet-derived growth factor; RA, rheumatoid arthritis; SF, synovial fluid; TGF, transforming growth factor; Th, T helper; TIMP, tissue inhibitor of metalloproteinase; TNF, tumor necrosing factor; TRAP, tartrate-resistant acid phosphatase.

* Corresponding author. Tel.: +3292647700.

E-mail address: marjandoom@hotmail.com (M. Doom). 
This review provides a comprehensive overview of all possible implications of humoral and cell-mediated immune responses published in dogs with cruciate disease together with publications from human joint diseases. Furthermore, this review highlights recent findings on cytokines and proteinases in the accompanying joint inflammation.

(C) 2008 Elsevier B.V. All rights reserved.

Keywords: Antibodies; Cranial cruciate ligament; Cytokines; Dog; Osteoarthritis; Matrix metalloproteinase

\section{Introduction}

Rupture of the cranial cruciate ligament (CrCL) is one of the most important causes of hindlimb lameness in dogs. While acute ligament injury may occur because of a single event overload from trauma, the majority of dogs rupture their $\mathrm{CrCL}$ during normal daily activities due to secondary progressive and irreversible degenerative changes within the ligament itself (Zahm, 1965; Pond and Campbell, 1972; Arnoczky and Marshall, 1981; Moore and Read, 1996; Narama et al., 1996). This form of nontraumatic rupture is clinically termed spontaneous CrCL rupture. In addition one third of the cruciate patients rupture their contralateral $\mathrm{CrCL}$ within 8 months after rupture of the CrCL in the initially affected stifle joint (Strande, 1967; Pond and Campbell, 1972; Bennett et al., 1988; Doverspike et al., 1993). Partial or complete rupture of the CrCL results in stifle joint instability and contributes significantly to the development of osteoarthritis (OA) (Tirgari, 1977; Elkins et al., 1991). OA is a highly prevalent degenerative joint disorder in both animals and humans. It is a progressive disease that is associated with pain, stiffness and decreased range of movement. There are no consistently effective methods for preventing the development of $\mathrm{CrCL}$ degeneration or slowing its progression. The etiopathogenesis of $\mathrm{CrCL}$ disease in dogs remains unsolved in the majority of cases although a great deal of attention has already been concentrated on trying to identify factors that might lead to the structural failure of the ligament. Rupture of the CrCL has been associated with age-related ligament deterioraton (Vasseur et al., 1985), ligament deterioration due to lack of exercise (Tipton et al., 1970), plasmocytic lymphocytic synovitis (Hopper, 1993), and conformation abnormalities (Read and Robins, 1982; Slocum and Slocum, 1993). Many of these suggested mechanisms are still believed to be relevant in spontaneous CrCL rupture, but none of them alone satisfactorily explains the etiopathogenesis of this disease. Multiple factors may lead to rupture of the CrCL and the subsequent development of osteoarthritis (OA). A better knowledge of the disease mechanisms in canine CrCL rupture would enable us to accurately alter the degenerative processes. May be, prophylactic measures could be taken in the future. Humoral as well as cell-mediated immune responses are illustrated in canine cruciate disease. Nevertheless, there is increasing evidence that joint inflammation precedes CrCL clinical rupture in dogs with cruciate disease.

\section{Humoral immunity in cruciate disease}

The cruciate ligaments are covered by a fold of synovial membrane and, although they have an intraarticular position, they are in fact extra-synovial (Alm and Strömberg, 1974; Arnoczky et al., 1979). Due to the protective synovial layer, the cruciate ligaments are secluded from immune surveillance, and for this reason they can act as self-antigens for autoantigenicity in cases of damage (Osborne et al., 1995; Kobayashi et al., 2006). One of the major components of joint tissue is collagen. The cruciate ligaments and menisci are mainly composed of collagen type I whereas the articular cartilage is mainly composed of collagen type II (van Sickle et al., 1993). Upon damage of these structures, antigen is released in the SF, capable of evoking an immune response (Fig. 1). Joint aspirates from human patients with arthritis often contain wear particles, for example, collagen, proteoglycan, bone, uric acid, fibronectin, crystals and other, as yet unidentified, materials (Evans et al., 1984; Xie et al., 1992; Lohmander et al., 1993, 1994; Manicourt et al., 2000; Nalbant et al., 2003). Some of these wear particles have also been identified in the SF of dogs with arthropathy (Arican et al., 1994; Innes et al., 1998; Chu et al., 2002). The significance of these particles as initiators, promoters or result of OA is still unclear. Studies with animals have provided convincing evidence that cartilage is arthritogenic. Arthritis has been induced by intra-articular injection of allogenic cartilaginous particles into rabbit stifle joints (Evans et al., 1984). Also in canine stifle joints, OA, characterized by joint inflammation, joint stiffness and osteophyte formation, has been induced after intraarticular injections of autologous costal cartilage (Chrisman et al., 1965). Collagen-induced arthritis (CIA) in rodents inspired researchers to investigate 


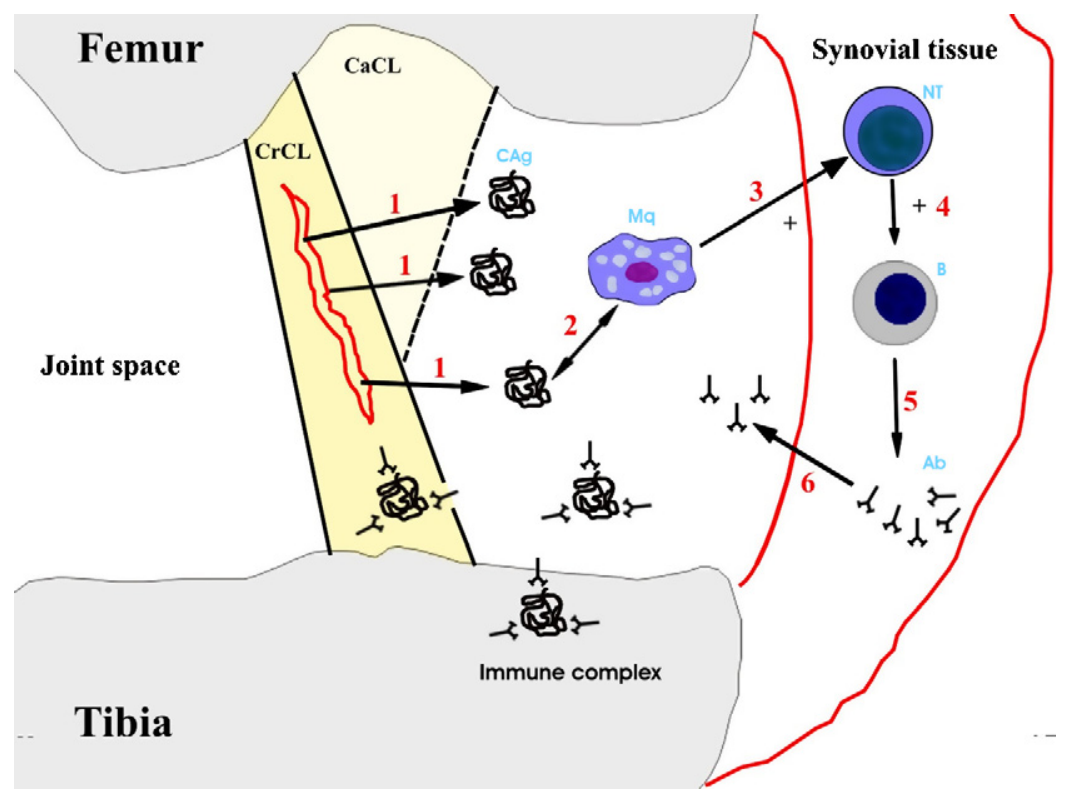

Fig. 1. Schematic representation of humoral immune response in dogs with cruciate disease. Step 1: impaired CrCL with release of collagen type I $(C A g)$, Step 2: collagen uptake by macrophage $(M q)$, Step 3: antigen presentation to naive T cell $(N T)$, Step 4: B cell $(B)$ activation/differentiation with antibody production $(A b)$, Step 5: release of antibodies in synovial tissue and Step 6: release of antibodies in the synovial fluid and formation of immune complexes with collagen type I.

autoimmunity to collagen type II in the pathogenesis of human RA, since the histopathology and nature of the immune response is similar in both diseases (Trentham et al., 1977; Courtenay et al., 1980). In CIA, collagen serves as a direct stimulus for the local production of anticollagen type II antibodies in the synovial tissue. These antibodies engage in the formation of complement-binding antigen-antibody complexes which are said to play a major part in the induction and perpetuation of synovial inflammation. In the SF of human patients with RA and OA, anticollagen antibodies (Menzel et al., 1976, 1978; Stuart et al., 1983; Jasin, 1985) and immune complexes (Cooke, 1980) have been discovered. In RA, these antibodies are produced locally by plasma cells that are located in the synovial tissue (Smiley et al., 1968). Also in dogs with RA and cruciate disease, anticollagen type I and II antibodies have been detected in both sera and SF, with a higher incidence in the SF thus indicating a local antibody production (Niebauer and Menzel, 1982; Niebauer et al., 1987; Bari et al., 1989). Histological studies on synovial tissue from stifle joints of dogs with cruciate disease also support the belief that anticollagen antibodies are produced locally within the synovial tissue (Hewicker et al., 1999; Tirgari, 1977; Galloway and Lester, 1995; Lawrence et al., 1998). The main cell types detected in the synovial tissue are macrophages, T-lymphocytes, B-lymphocytes and plasma cells belonging predominantly to the $\mathrm{IgG}$ isotype (Hewicker et al., 1999; Tirgari, 1977; Galloway and Lester, 1995; Lawrence et al., 1998; Lemburg et al., 2004). A significant higher amount of $\operatorname{IgG}$ and $\operatorname{IgM}$ has been detected in the synovial tissue of stifle joints of dogs with cruciate disease compared to normal stifle joints (Lawrence et al., 1998). In addition, one study reported that $67 \%$ of the dogs had distinct lymphoplasmacytic nodules within the synovial tissue (Galloway and Lester, 1995). However, up to date no synovial tissue cells from cruciate patients have been cultured to discover if they effectively produce antibodies. Therefore, it remains uncertain whether antibodies play an active role in the initiation of $\mathrm{CrCL}$ rupture. Anticollagen type I and II antibodies have also been detected in the SF of stifle joints with OA secondary to arthropathies other than CrCL rupture, suggesting that these antibodies are not specific for the type of joint disorder (de Rooster et al., 2000). A prospective study in which anticollagen type I antibodies have been measured sequentially over a $12-18$ months period in the SF of dogs initially presented with unilateral CrCL rupture, could not provide evidence that anticollagen antibodies initiated CrCL damage in dogs, since not all dogs with high antibodies developed a contralateral CrCL rupture (de Bruin et al., 2007a). Nevertheless, it is possible that anticollagen antibodies perpetuate chronic joint inflammation in some dogs with cruciate 
deterioration, even if collagen is not the primary arthritogenic agent. In predisposed dogs, higher anticollagen type I titers were found in the stifle joints that eventually sustained a CrCL rupture, compared to the titers in a remote joint. This finding suggests that there was an inflammatory process with production of collagen-specific antibodies, present in these joints before detectable joint instability occurred (de Bruin et al., 2007a). Antigens can also maintain joint inflammation by forming immune complexes with antibodies. In antigen-induced arthritis in rabbits, large amounts of the inducing antigen persists for long periods of time in the form of immune complexes within the cruciate ligaments (Cooke et al., 1972). In addition, marked disorganized cellular architecture, loss of fiber orientation and infiltration of mononuclear and polymorphonuclear cells were demonstrated within the cruciate ligaments of these animals (Goldberg et al., 1982). Persistence of the antigen is believed to be responsible for the chronicity of the joint inflammation and contribute to the degeneration of the cruciate ligaments resulting in decreased mechanical strength (Goldberg et al., 1982).

\section{Cell-mediated immune response in cruciate disease}

Variable amount of synovitis, with an inflammatory infiltrate (mainly characterized by B- and T-lymphocytes, macrophages and $\mathrm{IgG}+, \operatorname{IgM}+$ and $\mathrm{IgA}+$ plasma cells), is present in the stifle joints of dogs with cruciate disease (Galloway and Lester, 1995; Lemburg et al., 2004). The significance of these inflammatory cells is still poorly understood. It has been suggested that they are indicative of a cell-mediated immune response (Galloway and Lester, 1995). Studies in dogs with CrCL rupture detected many MHC class II antigen positive cells morphologically resembling dentritic cells in the synovial tissue of affected stifle joints (Hewicker et al., 1999; Lemburg et al., 2004). These cells can be involved in the activation of naive $\mathrm{T}$ helper (Th) cells which will differentiate towards $\mathrm{Th}_{1}, \mathrm{Th}_{2}$ and the more recently discovered $\mathrm{Th}_{17}$ (Jin et al., 2008). It has become apparent in recent years that the immune responses driven preferentially by activated Th subsets are involved in the development of pathological immune disorders. Although an attempt to dichotomize complex diseases in terms of just Th1 or Th2 may be an oversimplification, the concept not only clearly allows better understanding of the mechanisms involved in the pathogenesis of the disease but also provide the basis for the development of novel strategies for treatment.
Currently there is convincing evidence that $\mathrm{Th}_{1}$ cells play a central role in initiating and perpetuating the chronic joint inflammation in RA and OA (Schultze and Kalden, 2001; Miltenburg et al., 1992; Bucht et al., 1996; Kanik et al., 1998; Canete et al., 2000; Davis et al., 2001). This could lead to massive activation of the synovial macrophages that are present in the synovial tissue. In mice with experimentally induced stifle joint instability, recent immunohistochemical studies discovered many activated (MRP (myeloid related protein) 8 and MRP14 positive) synovial lining macrophages in the synovial tissue (Blom et al., 2004; van Lent et al., 2004). In these studies, results strongly suggest that the synovial lining macrophages are fundamental in mediating osteophyte formation and, since selectal removal of the lining macrophages by clodronate-laden liposomes significantly blocked osteophyte formation (Blom et al., 2004; van Lent et al., 2004). $\mathrm{Th}_{17}$ cells have been shown to play a cruciate role in the induction of autoimmune tissue injuries, inflammation and infection (Jin et al., 2008).

The question which remains to be answered is what causes the immune reactions in canine cruciate disease. In human patients with $\mathrm{OA}$, denatured cartilaginous detritus have been detected in the lysosomes of synoviocytes (Saito et al., 2002). Immunohistochemical staining of these cells showed that they were of the macrophage lineage (CD68-positive cells) (Saito et al., 2002). This could mean that the denatured cartilaginous detritus is recognized as an intra-articular foreign body, and is phagocytized and processed. It could be hypothesized that in CrCL rupture, antigen presenting cells take up and process joint-derived antigens such as collagen type I and II and present it to naive Th cells. Currently there is no evidence of follicular lymphoplasmatic inflammatory change with germinal centra in the synovium of dogs with spontaneous CrCCL rupture (Lemburg et al., 2004), which suggests the absence of local antigen presentation. A number of findings in dogs with $\mathrm{CrCL}$ rupture suggest that joint inflammation is possibly initiated and perpetuated by the response of Th cells to antigenic peptides presented by antigen presenting cells. For instance, immunohistochemical studies have detected MHC class II- and $\mathrm{CD} 1_{\mathrm{c}}$ expressing dendritic cells clustered with lymphocytes, largely composed of $\mathrm{CD}^{+} \mathrm{T}$ cells, in the synovial tissue of stifle joints from dogs with cruciate disease (Lemburg et al., 2004). Flow cytometric analysis of canine SF cells isolated from normal and cruciate deficient stifle joints, showed higher percentages of mainly $\mathrm{CD}^{+} \mathrm{T}$ cells in the affected stifle joints (Faldyna et al., 2004a,b). Only a slight increase in CD8 ${ }^{+}$ 
$\mathrm{T}$ cells was found. In addition, the amount of lymphocytes expressing the CD45RA isoform is significantly decreased in SF of the affected stifle joints (Faldyna et al., 2004a,b). CD45RA expression in humans is restricted to $B$ cells and naive $T$ cells (Lydyard and Grossi, 1993). This suggests that cells in the SF of cruciate deficient stifle joints are activated by an antigen. Up to date the exact distribution of CD45RA among lymphocytes in dogs has not been examined. However, the expression of the different CD45 isoforms show a characteristic pattern of cellular distribution, which is conserved throughout mammalian revolution (Thomas, 1989). Moreover, a similar age-related difference in the distribution of CD45RA positive cells between dogs and humans is observed (Felsburg, 2002). These findings suggest a similar distribution of CD45RA positive cells in dogs and humans. Another study examining synovial macrophages in the synovial tissue of dogs with cruciate disease found that the cell density was associated with the severity of radiographic OA (Klocke et al., 2005). The higher percentage of activated $\mathrm{CD}^{+}{ }^{+} \mathrm{T}$ cells and synovial macrophages in cruciate disease are suggestive of a $\mathrm{Th}_{1}$ response. So, it is possible that collagen type $\mathrm{I}$, released from the impaired $\mathrm{CrCL}$, is presented to naive Th cells resulting in a $\mathrm{Th}_{1}$ response with activation of macrophages (Fig. 2). These macrophages could phagocytize the free collagen type I antigens and/or the immune complexes and release proteinases that further damage the impaired CrCL. In a recent study lymphocyte reactivity to collagen type I was assessed in dogs with cruciate disease by culturing peripheral blood mononuclear cells with human collagen type I, and was compared to sham operated and normal dogs. This study demonstrated that lymphocyte reactivity to collagen type I does occur in dogs with CrCL rupture, however, some of the sham operated dogs and healthy dogs tested positive as well (de Bruin et al., 2007b). In addition, PBMC proliferation to collagen type I was very diverse in dogs that sustained a CrCL rupture in the contralateral stifle joint, suggesting that collagen reactive $\mathrm{T}$ cells do not play a primary role in CrCL disease. It is possible, however, that the reactive T-lymphocytes home to the stifle joints and initiate a local immune response. Further research is required to determine whether cellular reactivity to collagen type I exists locally in the stifle joints and if they could initiate cruciate degradism.

\section{Cytokines and joint inflammation}

In human patients with ACL injury and dogs with $\mathrm{CrCL}$ injury, OA continues to develop despite surgical restoration of the joint stability. This has lead to the suggestion that biomechanical stresses together with biochemical factors are responsible for the OA changes (Elkins et al., 1991; Cameron et al., 1994, 1997; Rayward et al., 2004). Biochemical factors that have received massive attention as possible candidates for inducing and perpetuating joint inflammation are proinflammatory cytokines (Shinmei et al., 1990; Yuan et al., 2003; Goldring, 1999). Some cytokines can worsen disease (pro-inflammatory), whereas others can reduce inflammation and promote healing (anti-inflammatory). Importantly, cytokines can influence the outcome of an inflammatory response by exerting effects on various stages of the immune response. There is compelling evidence that certain cytokines play an important role in joint inflammation and cartilage degradation in diseased and/or damaged joints such as interleukin IL-1, IL-6 and tumor necrosis factor TNF- $\alpha$ as well as IL-8. Cytokine profiles have been studied in human patients with ACL injury (Cameron et al., 1994, 1997; Irie et al., 2003) and there seems to be an imbalance between the pro-inflammatory (TNF- $\alpha$, IL$1 \beta$, IL-6, IL-8) and anti-inflammatory cytokines (IL1ra, IL-10). This imbalance could have the potential to engender cartilage loss and eventually lead to OA (Cameron et al., 1994, 1997). There are also immunoregulatory mechanisms present in the joint (Brennan et al., 1995; Bucht et al., 1996). The two major immunoregulatory factors present in the joint are the cytokine inhibitors and the growth factors. Immunoregulatory factors are up-regulated in humans with chronic joint inflammation, however, they are apparently insufficient to ablate the inflammation as proinflammatory bioactivity is still detected in the diseased joints (Brennan et al., 1995). Studies on pro- and antiinflammatory cytokines and immunoregulatory mechanisms in dogs with joint disease are only in the begin phases (Fernihough et al., 2003). Fig. 3 describes the important pro- and anti-inflammatory cytokines, cytokine inhibitors and growth factors that could play a role in canine cruciate disease based on studies examining human joint pathologies, animal models of OA or arthritis and studies examining various arthropathies in dogs.

\subsection{Pro-inflammatory cytokines}

The cytokines IL-1 and TNF- $\alpha$ are primarily proinflammatory cytokines and, although they are structurally unrelated and bind to different receptors, they share remarkable similarities in biological activities, often working synergistically. Both IL- 1 and TNF- $\alpha$ are 


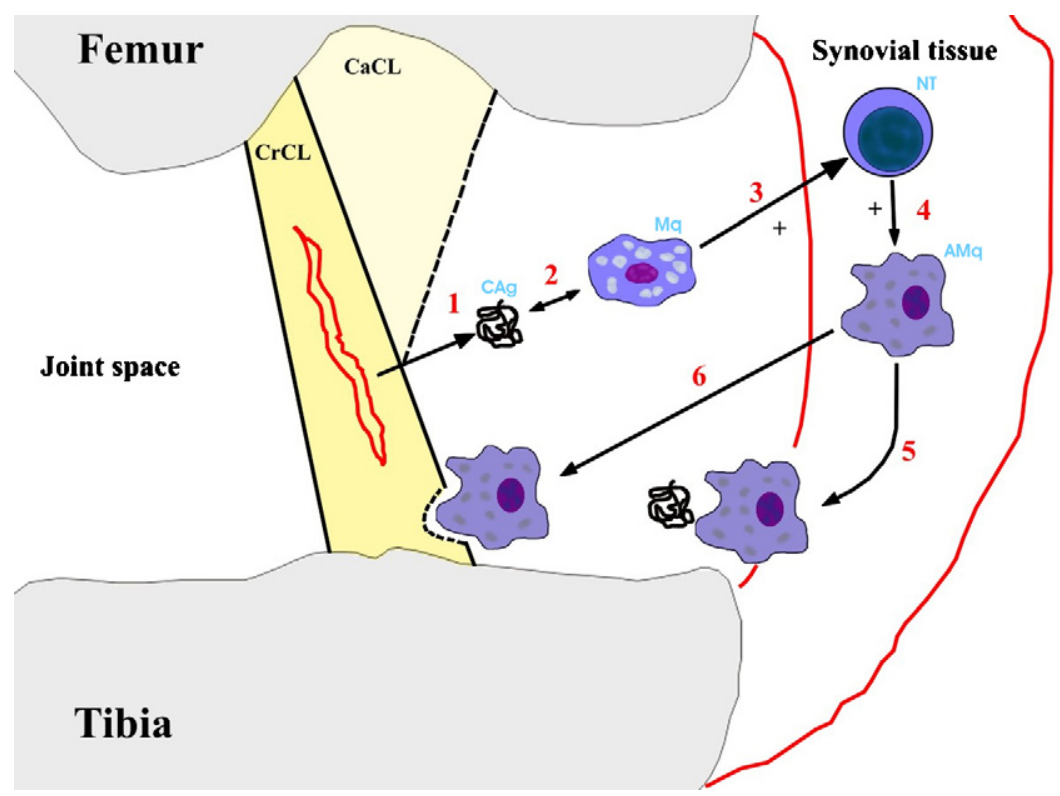

Fig. 2. Schematic representation of cellular immune response in dogs with cruciate disease. Step 1: impaired CrCL with release of collagen type I $(C A g)$, Step 2: collagen uptake by macrophage $(M q)$, Step 3: antigen presentation to naive T cell (NT), Step 4: macrophage activation (AMq), Step 5: phagocytosis of free collagen and Step 6: proteolytic degradation of the injured CrCL.

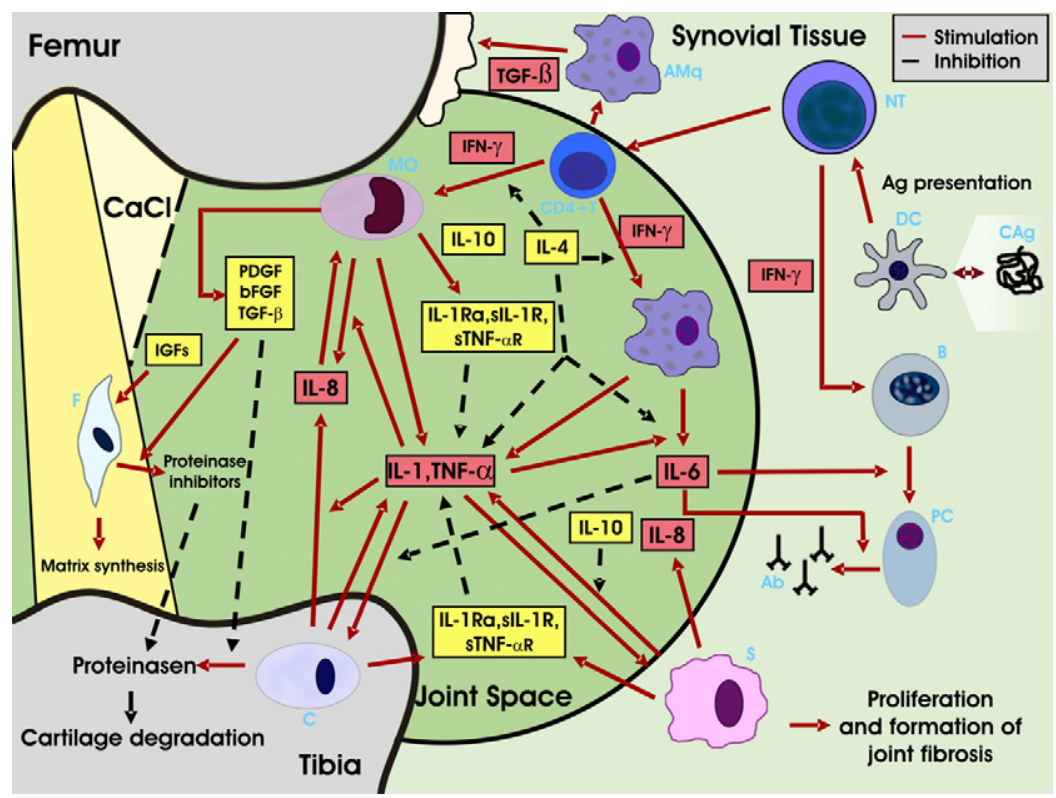

Fig. 3. Schematic representation of the possible cytokine cascade in dogs with CrCL rupture (begin at the antigen presentation in the synovial tissue; black lines: stimulation; red lines: inhibition, green boxes: pro-inflammatory, red boxes: anti-inflammatory). Antigen stimulated dendritic cells present antigen to naive T-lymphocytes. Activated CD4+ T-lymphocytes can then stimulate different cells (macrophages, monocytes, Blymphocytes, fibroblasts and synoviocytes) by cytokine release to produce antibodies, osteophytes, ligament degeneration and synovial tissue proliferation (black lines). Next to the pro-inflammatory reactions, anti-inflammatory responses are seen (red lines). Ab: antibodies, Ag: antigen, AMq: activated macrophage, B: B-lymphocyte, bFGF: basic fibroblast growth factor, C: chondrocyte, CaCL: caudal cruciate ligament, CAg: collagen antigen, CD4+T: CD4+ T-lymphocyte, DC: dendritic cell, IFN- $\gamma$ : interferon gamma, IGFs: insulin-like growth factors, Il: interleukin, Il1Ra: interleukin 1 receptor antagonist, F: fibroblast, Mo: monocyte, NT: naive T-lymphocyte, PC: plasma cell, PDGF: platelet-derived growth receptor, S: synoviocyte, sIL-1R: soluble IL-1 receptor, sTNF- $\alpha$ R: soluble TNF- $\alpha$ receptor, TGF- $\beta$ : transforming growth factor beta, and TNF- $\alpha$ : tumor necrosis factor alpha. (For interpretation of the references to color in this figure legend, the reader is referred to the web version of the article.) 


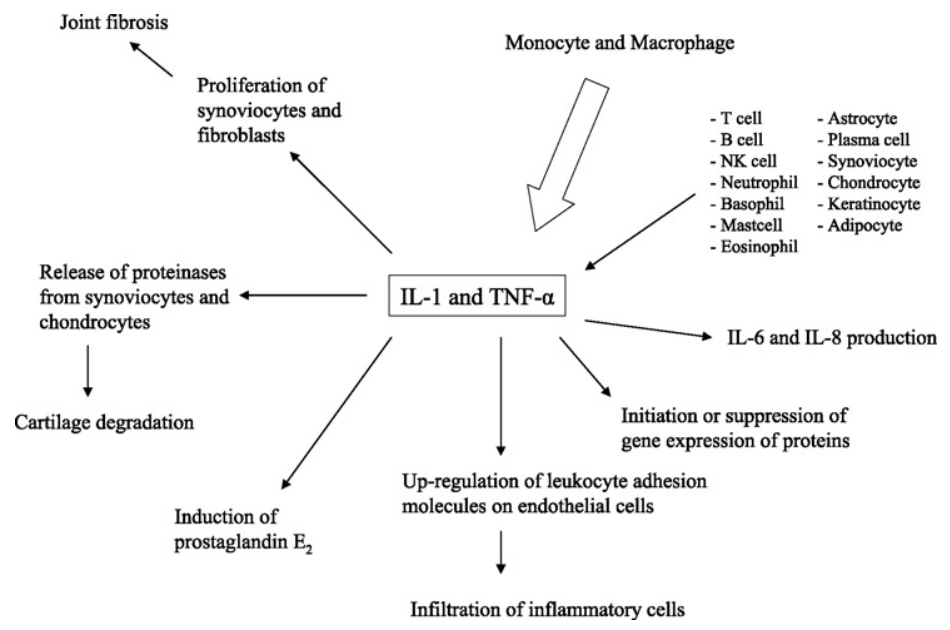

Fig. 4. Schematic representation of Il-1 and TNF- $\alpha$ properties in joint pathologies.

involved in a number of physiological and pathophysiological processes (Fig. 4) and are produced during inflammation, injury, immunological challenge or infection (Tracey, 1994). Cells from the monocyte/ macrophage lineage are the principle source of IL-1 and TNF- $\alpha$, however, a variety of cells are capable of secreting them, e.g. B cells, T cells, natural killer cells, mast cells, neutrophils, basophils, eosinophils, keratinocytes, plasma cells, adipocytes, astrocytes and synoviocytes (Tracey, 1994; Wood et al., 1985; Sukedai et al., 2004). IL-1 and TNF- $\alpha$ initiate or suppress gene expression of several proteins and promote inflammatory cell infiltration by up-regulating leukocyte adhesion molecules on endothelial cells (Hulkower et al., 1994). They also induce prostaglandin $\mathrm{E}_{2}\left(\mathrm{PGE}_{2}\right)$ production that induces vascular permeability and, therefore, an increased infiltration and activation of inflammatory cells (Hulkower et al., 1994). IL-1 and TNF- $\alpha$ are thought to be the main cytokines responsible for cartilage loss as they stimulate chondrocytes and synoviocytes to produce various enzymes (Shinmei et al., 1990). Both cytokines augment the proliferation of fibroblasts and synovial cells, which results in the formation of joint fibrosis (Pelletier et al., 1996).

IL- 1 and TNF- $\alpha$ are the first cytokines generated by activated monocytes and macrophages in CIA and human RA. They stimulate synoviocytes, chondrocytes and osteoblasts to produce more IL- 1 and TNF- $\alpha$, thus amplifying the cytokine concentrations and resulting in severe inflammation (Joosten et al., 1996; Bertazzolo et al., 1994; Cheon et al., 2002). In humans with primary OA, IL-1 is also the most abundantly synthesized proinflammatory cytokine by the synovial tissue (Pelletier et al., 1993a), however, it is hardly detectable in their SF
(Bertazzolo et al., 1994; Holt et al., 1992; Kaneyama et al., 2002). In humans with secondary OA due to ACL injury, no difference in SF IL-1 levels has been found by ELISA between the injured knee joints and the healthy knee joints (Cameron et al., 1994, 1997). Nevertheless, IL-1 bioactivity is not only influenced by its absolute amount present in the SF but also by the number of receptors and specific inhibitors. Increased expression of IL-1 receptor type I on chondrocytes and synovial fibroblasts in human OA has been detected (MartelPelletier et al., 1992; Sadouk et al., 1995). In addition, the percentage of receptor occupancy required to elicit enzyme stimulation is significantly lower in human OA cells than in normal cells (Martel-Pelletier et al., 1992). For example, osteoarthritic chondrocytes only need approximately $1 \%$ receptor occupancy, while normal chondrocytes require 4\% (Martel-Pelletier et al., 1992). This suggests that even a small amount of bioactive IL-1 present in the SF could perpetuate joint inflammation in human OA, and perhaps also in ACL injured knee joints. In dogs with arthropathy, conflicting results are found for the cytokine IL-1. Dogs with immunemediated polyarthritis have high IL-1 $\beta$ gene expression in isolated SF cells (Hegemann et al., 2005). Yet, SF IL1 bioactivity is only found in $8 \%$ of the samples (Carter et al., 1999). In dogs with experimentally transected CrCL (Pond-Nuki model), bioactivity of IL-1 varied from undetectable to increased in the operated stifle joints (Carter et al., 1999; Fernandes et al., 1997). Significant higher levels were found by bioassay in the SF of dogs with naturally occurring CrCL rupture compared with SF of normal dogs (Fujita et al., 2006). An increase in IL-1 positive cells is also detected in the synovial tissue and cartilage of the Pond-Nuki dogs 
(Pelletier et al., 1993b). It is possible that also in dogs with arthropathy, small amounts of IL-1 is sufficient for maintaining joint inflammation, however, more research is needed on this matter.

It was generally believed that TNF- $\alpha$ is primarily involved in the acute phase of joint inflammation (Cameron et al., 1997; Joosten et al., 1996; Bolon et al., 2004). However, it is now clear that this cytokine also has a function in chronic joint inflammation (Sukedai et al., 2004; Emshoff et al., 2000). High levels of TNF- $\alpha$ are detected by ELISA in the SF of human patients with chronic RA (Isomaki et al., 1996; Lettesjo et al., 1998; Petrovic-Rackov and Pejnovic, 2006). In addition, clinical trials targeting TNF- $\alpha$ (anti-TNF- $\alpha$ antibodies, soluble TNF- $\alpha$ receptors) ameliorate disease symptoms in patients with acute and chronic RA (Brennan et al., 1995; Macias et al., 2005). Also in joints with chronic ACL injury, TNF- $\alpha$ levels remain elevated (Cameron et al., 1997; Irie et al., 2003; Marks and Donaldson, 2005). These studies provide evidence that TNF- $\alpha$ contributes to the pathogenesis of these diseases, even in the chronic stages. In dogs with RA, spontaneous $\mathrm{CrCL}$ rupture and experimentally transected $\mathrm{CrCL}$, TNF- $\alpha$ bioactivity in the SF varied from undetectable to elevated (Carter et al., 1999; Venn et al., 1993; Fujita et al., 2006; Hay et al., 1997). Recently, TNF- $\alpha$ mRNA expression has been detected in SF cells from dogs with immune-mediated arthritides and spontaneous $\mathrm{CrCL}$ rupture, with higher levels in the immune-mediated group (Hegemann et al., 2005). These studies did not correlate disease duration in function of TNF- $\alpha$ activity. It is therefore difficult to conclude which role TNF- $\alpha$ plays in dogs with arthropathy. Furthermore, Il-1 assays and the TNF $\alpha$ assays used may have detection limits which are not as low as the levels at which these cytokines function biologically, so that the inability to demonstrate their activity in the synovial fluids does not exclude the possibility that the cytokines are present at functional levels (Carter et al., 1999). Another important inflammatory cytokine is IL-6, a multifunctional cytokine that can be produced by most, if not all, cell types, especially upon stimulation with IL-1 and TNF- $\alpha$ (Shinmei et al., 1990; Hirano, 1994). It regulates immune responses, haemopoiesis and is the most important inducer of the hepatic acute-phase response (Hirano, 1994). Although IL-6 does not exhibit any of the pro-inflammatory properties of IL- 1 and TNF- $\alpha$, it is a potent $B$ cell growth and differentiation factor (Hirano, 1994). Therefore, it can indirectly exacerbate inflammation through augmentation of antibodies against collagen or other joint antigens. Intriguingly, although IL-6 is considered an inflammatory cytokine, it also possesses anti-inflammatory properties. IL-6 inhibits proteolytic enzyme production by IL-1 and TNF- $\alpha$ stimulated chondrocytes, thereby decreasing cartilage destruction (Shinmei et al., 1990, 1991). In human patients with various inflammatory arthritides, high levels of IL-6 is detected in the SF by ELISA, as well as in the SF from human patients with primary OA and ACL injury (Cameron et al., 1994, 1997; Irie et al., 2003; Raza et al., 2005). The levels detected by bioassay, are positively correlated with both the clinical and laboratory parameters of inflammation in the same joint (Miltenburg et al., 1991). These studies implicate that IL-6 is a possible marker of joint inflammation in general, but not of a specific joint pathology. Cytokine studies of dogs with various arthropathies also implicate IL-6 as a general indicator of joint inflammation. Dogs with natural occurring and experimentally induced CrCL rupture have higher IL-6 bioactivity in their SF compared with healthy dogs (Carter et al., 1999; Venn et al., 1993; Fujita et al., 2006; Hay et al., 1997), SF of dogs with CRA have significant higher IL-6 bioactivity than dogs with natural occurring CrCL rupture (Carter et al., 1999). Higher IL-6 gene expression is also detected in SF cells from dogs with immune-mediated polyarthritis compared with that from dogs with natural occurring CrCL rupture (Hegemann et al., 2005). Higher levels of IL-6 found in inflammatory arthritides is in accordance with the higher amount of joint inflammation seen in these joints. The presence of higher amounts of IL- 6 in the synovial fluid of OA and RA joints in comparison with IL-1 and TNF- $\alpha$ may possibly be due to induction during the disease process, possibly by transient peaks of IL-1 and TNF activity, and enhanced by binding with soluble IL-6 receptors (Carter et al., 1999).

The involvement of chemokines in joint inflammation and cartilage degradation has recently been revealed (Peichl et al., 1992; Borzi et al., 1999; Kirkham et al., 1999; Lisignoli et al., 1999). Chemokines selectively enhance the migration and activation of particular subpopulations of leukocytes (Male, 1993). Studies of chemokine expression have provided strong evidence for their involvement in the pathogenesis of human RA and OA, especially for the chemokine IL-8 (Endo et al., 1991; Furuzawa and Alocer, 1999; Kaneko et al., 2000). IL-8 is one of the most potent chemo-attracting factors for neutrophils and $\mathrm{T}$ cells, both in vitro and in vivo (Endo et al., 1991; Larsen et al., 1989; Akahoshi et al., 1994). In the presence of IL-1, TNF- $\alpha$ and lipopolysaccharide, IL- 8 is produced by a variety of cells, including leukocytes, fibroblasts, endothelial cells, chondrocytes, and synoviocytes 
(Sukedai et al., 2004; Furuzawa and Alocer, 1999; Hirota et al., 1992; Deleuran et al., 1994a; Van Damme, 1994; Ogura et al., 2005). Besides attracting polymorphonuclear cells, IL-8 also induces expression of adhesion molecules, neutrophil degranulation and production of oxygen metabolites (Baggiolini et al., 1994), thereby able to cause tissue damage. IL- 8 has been detected in high levels by bioassay in the SF of human patients with RA and in a lower concentration in the SF of human patients with primary OA (Furuzawa and Alocer, 1999; Symons et al., 1992). High levels of IL-8 have also been detected by ELISA in the SF of ACL injured knee joints (Cameron et al., 1994, 1997; Irie et al., 2003). Up to date, only the gene expression of IL-8 has been examined in dogs with different arthropathies. Higher expression was detected in inflammatory arthritides compared with the expression in cruciate disease according to Hegemann et al. (2005), whereas no significant difference in gene expression has been detected in canine OA differing in etiopathogenesis (de Bruin et al., 2005). In a more recent study in dogs presented with unilateral CrCL rupture, IL-8 expression was found in the affected stifle joint and not in the contralateral stifle joint at time of admission. However, at rechecks, the IL- 8 expression tended to be higher in the non-operated contralateral stifle joints that will rupture their CrCL during the next 6 months than in those that will not. This finding suggests the presence of an inflammatory process in these joints before CrCL rupture becomes clinical apparent (de Bruin et al., 2007c).

Another important cytokine is interferon (IFN)- $\gamma$. IFN- $\gamma$ can be considered inflammatory because it augments TNF- $\alpha$ activity and induces nitric oxide (Sebbag et al., 1997). It also stimulates naive Th cells to evolve into $\mathrm{Th}_{1}$ cells, thereby favoring cellular immunity. Intriguingly, IFN- $\gamma$ also has anti-inflammatory activities since it possesses antiviral activity, activates $T$ cells to become cytotoxic T cells and inhibits IL-1, IL-8 and metalloproteinase production by synoviocytes (Ghezzi and Dinarello, 1988; Seitz et al., 1994). Data concerning the role of IFN- $\gamma$ in septic antigen-induced arthritis are conflicting. IFN- $\gamma$ displays inflammatory properties when administered intravenously in the initiation phase whereas it ameliorates joint inflammation when administered later in the disease process (Puliti et al., 2000). In human RA, clinical trials with IFN- $\gamma$ only showed partial and temporal benefit (Cannon et al., 1989; Cannon et al., 1993) or no significant improvement (Veys et al., 1997). The presence and possible role of IFN- $\gamma$ in canine cruciate disease has not been extensively studied. Its gene expression appears to be slightly higher in SF cells of stifle joints from CrCL rupture than from immunemediated arthritis (Hegemann et al., 2005).

\subsection{Immunoregulatory mechanisms}

\subsubsection{Cytokine inhibitors}

Cytokine inhibitors are of considerable therapeutic interest for ameliorating chronic inflammatory diseases. Two main categories of cytokine inhibitors exist: the receptor antagonist and the soluble cytokine receptors. One specific receptor antagonist has been studied extensively, namely the interleukin-1 receptor antagonist (IL-1Ra). IL-1Ra shares a high degree of homology with IL-1 and is capable of binding to the IL-1 receptors on cell surfaces without transducing a signal (Arend et al., 1990; Arend, 1993), thereby inhibiting IL-1. It is produced by several cell types, including monocytes, synoviocytes and chondrocytes (Arend et al., 1990; Caron et al., 1996). A 100-fold excess of IL-1Ra must be present in order to effectively block the effects of IL1 since target cells exhibit full biological response even when only a small percentage of the IL-1 receptors on each cell are occupied (Arend et al., 1990). In human patients with RA and OA, a relative deficit in the production of IL-1Ra has been detected in the synovial tissue (Firestein et al., 1994; Fujikawa et al., 1995). Also in the SF of human patients with chronic ACL injury, significant less IL-1Ra levels was detected (Cameron et al., 1994, 1997; Irie et al., 2003; Marks and Donaldson, 2005). Thus, without sufficient neutralizing levels of IL-1Ra, even low levels of IL-1 are sufficient for maintaining joint inflammation. Up to date, the presence and possible role of IL-1Ra in canine cruciate disease has not been examined. However, since in human medicine the administration of IL-1RA into the joint space has been suggested to influence the clinical course of painful and debilitating forms of arthritis (Arend, 1993), it would be worthwhile to do this.

Soluble truncated versions of membrane cytokine receptors have been isolated in normal and abnormal biological fluids from humans and mice (Fernandez, 1991). These soluble cytokine receptors are involved in the regulation of cytokine activity (Fernandez, 1991). They act as competitive inhibitors with the membrane cytokine receptors for the binding of cytokines, thereby inhibiting subsequent signal transduction (Fernandez, 1991). They bind to IL-1 but not to IL-1Ra (Symons et al., 1991). Many soluble cytokine receptors have been identified to date (Fernandez, 1991), however, the most investigated in regard to arthritis are those for IL-1 and TNF- $\alpha$. Soluble IL-1 type II receptors have been 
detected in the SF of human patients with OA (Kaneyama et al., 2005). Soluble TNF receptors are increased in the sera and SF of patients with RA (Cope et al., 1992). Antagonism of TNF- $\alpha$ bioactivity via the use of soluble TNF receptors has resulted in beneficial effects in preclinical animal studies. Patients with active RA, polyarticular juvenile chronic arthritis, psoriatic arthritis and ankylosing spondylitis are successfully treated with a recombinant human TNF- $\alpha$ receptor fusion protein (Cole and Rabasseda, 2004). To the authors' knowledge, soluble cytokine receptors have not been investigated in canine cruciate disease. Knowing that $\mathrm{CrCL}$ rupture in dogs has a moderate to severe inflammatory component, it would be worthwhile to investigate the presence, role and possible therapeutic use of these inhibitors in cruciate disease, in the hope to prevent rupture in the future.

\subsubsection{Growth factors}

Growth factors are proteins that enhance wound healing in damaged tissues. An immunohistochemical study in rabbits investigated the expression of growth factors in experimentally injured medial collateral ligaments and CrCL (Lee et al., 1998). Transforming growth factor (TGF)- $\beta$, platelet-derived growth factor (PDGF) and basic fibroblast growth factor (bFGF) were detected in vivo in the ligaments in the early healing stage (Lee et al., 1998). There were differences in staining between the $\mathrm{CrCL}$ en the medial collateral ligament, namely, the $\mathrm{CrCL}$ showed limited staining that was restricted to the edges of the lesion, whereas intensive staining of the total lesion was seen in the medial collateral ligament (Lee et al., 1998). This suggests that there could be a shortage of growth factors in the injured $\mathrm{CrCL}$ and could be a possible explanation why injured cruciate ligaments heal poorly.

TGF- $\beta$ is chemotactic for fibroblasts and stimulates the synthesis of collagen and non-collagenous protein in fibroblasts of $\mathrm{CrCL}$ and medial collateral ligament (Postlethwaite et al., 1987; Marui et al., 1997). TGF- $\beta$ suppresses the production of a wide diversity of proteolytic enzymes including the metalloproteinases (MMP), and stimulates the synthesis of their respective inhibitor (Kerr et al., 1990; Overall et al., 1989; Uria et al., 1998). Intra-articular administration of TGF- $\beta$ in experimentally overstretched CrCL injury in rabbits significantly enhanced the stiffness of the injured CrCL (Kondo et al., 2005). However, it did not restore the elongated CrCL back to its normal length. In a bonepatellar tendon-bone graft CrCL reconstruction in dogs, intra-articular administration of TGF- $\beta$, together with epidermal growth factor, improved the structural properties of the autograft (Yasuda et al., 2004). These studies suggest that application of TGF- $\beta$ has a positive effect on the collagen network in the injured CrCL and might have therapeutic use in an overstretched CrCL injury in dogs. However, the use of TGF- $\beta$ as a possible therapeutic agent must be studied more extensively since TGF- $\beta$ is also capable of promoting inflammation (Wahl et al., 1989). TGF- $\beta 1$ stimulates the gene expression of pro-inflammatory cytokines in synovial fibroblasts from human patients with RA and OA (Cheon et al., 2002). In an animal model of RA, intraarticular administration of TGF- $\beta$ induced an arthritis characterized by synovial hyperplasia and infiltration of leukocytes (Wahl et al., 1993). Intra-articular anti-TGF$\beta$ antibody treatment of these animals blocked not only the inflammatory cell accumulation but also the tissue pathology (Wahl et al., 1993). TGF- $\beta$ also stimulates the formation of osteophytes in mice with experimentally induced CrCL instability (Blom et al., 2004).

Insulin-like growth factors (IGF)-I and -II could possibly be used therapeutically in arthritis since they can reduce cartilage and ligament degradation by stimulating proteoglycan and collagen synthesis, even in the presence of IL-1 and TNF- $\alpha$ (Tyler, 1989; Hardingham et al., 1992). IGFs in vivo are predominantly bound to one of the six defined IGF-binding proteins (IGFBP) (Kelley et al., 1996; Baxter, 2000). IGFBPs are not simply passive carriers for the IGFs but have particular properties specific for each binding protein (Kelley et al., 1996; Baxter, 2000). Through different tissue expression and specific proteolysis of these binding proteins, IGFBP are able to stimulate and/ or inhibit the action of IGFs (Baxter, 2000). Thus, IGFBP can regulate the precise mechanism of action of IGF-I and -II (Kelley et al., 1996; Baxter, 2000; Jones and Clemmons, 1995). In human patients with RA and OA, a considerable increase in levels of IGF-I and -II are found in the SF compared with normal patients (Fernihough et al., 1996; Whellams et al., 2000). Levels of IGFBP-3 are also greatly enhanced together with a decrease in protease activity against this binding protein. Thus, a molar excess of IGFBP-3 to IGF exists whereas the opposite is found in normal SF (Whellams et al., 2000). This implies that, despite having an increased level of IGF-I and -II, the growth factors are predominantly bound to high-affinity binding proteins and are unable to bind to their receptors. In the SF of canine stifle joints with $\mathrm{CrCL}$ rupture, increased levels of IGF-I and -II are found after surgery. The concentration declined after 5 months but remained elevated compared with the contralateral stifle joints (Fernihough et al., 2003). These cruciate deficient 
stifle joints also had elevated levels of IGFBP-3 and -4 (Fernihough et al., 2003). Thus, even though the IGF system is elevated in canine CrCL rupture, its tissue availability may be limited due to alterations in IGFBP profiles.

\subsubsection{Anti-inflammatory cytokines}

Anti-inflammatory cytokines decrease the production and/or activities of inflammatory cytokines in vivo and in vitro (Goldring, 1999). Two important antiinflammatory cytokines are IL-4 and IL-10. Interleukin4 is a multifunctional cytokine that, in the joint, is only secreted by Th cells (Banchereau and Rybak, 1994; Sugiyama et al., 1995). It inhibits the production (spontaneous and induced) of IL-1, IL-6, IL-8, TNF- $\alpha$ and $\mathrm{PGE}_{2}$ by monocytes and synovial cell cultures isolated from human patients with RA (Seitz et al., 1994; Banchereau and Rybak, 1994; Sugiyama et al., 1995). IL-4 can enhance the antigen-presenting capacity of B cells towards CD4+ T cells, thereby favoring $\mathrm{T}$ and $\mathrm{B}$ cell interactions (Banchereau and Rybak, 1994). This leads to enhanced production of IgM, IgG and large amounts of IgE (Banchereau and Rybak, 1994). This property of IL-4 could be considered inflammatory, however, the overall effect of IL-4 in an inflammatory tissue will depend on the target cells, the differentiation status and the influence of other cytokines in the environment (Banchereau and Rybak, 1994).

Interleukin-10 is a natural suppressant of a number of inflammatory responses. It inhibits MHC class II expression on antigen presenting cells, $\mathrm{T}$ cell proliferation, production of IL- $1 \beta$ and TNF- $\alpha$ in activated synovial tissue cultures (Isomaki et al., 1996; Katsikis et al., 1994) and of IL-8 in SF and synovial tissue cell cultures (Deleuran et al., 1994b; Sugiyama et al., 1995). Furthermore, IL-10 up-regulates IL-1Ra expression in monocyte cultures (Katsikis et al., 1994). It also modulates TNF- $\alpha$ production by inducing the synthesis of the soluble TNF receptors whilst down-regulating the surface expression of the cytokine receptor (Brennan et al., 1995; Katsikis et al., 1994). IL-10 suppresses the release of reactive oxygen intermediates and nitric oxide in macrophages, thereby limiting tissue damage (Bogdan et al., 1991; Cenci et al., 1993). Interleukin-10 also has the capacity to promote antibody production (Mosmann, 1994), and it could contribute to the maintenance of local antibody production in RA synovial tissues (Lettesjo et al., 1998). Elevated levels of IL-10 and mRNA expression are detected in the SF and in the synovial tissue of human patients with RA and OA (Bucht et al., 1996; Isomaki et al., 1996;
Katsikis et al., 1994; Cush et al., 1995). Yet the levels of IL-10 are inadequate to reduce the inflammation and limit joint destruction (Isomaki et al., 1996). Also in dogs with CrCL rupture, gene expression of IL-10 is upregulated (Hegemann et al., 2005; de Bruin et al., 2007c), which might suggest that the immune system in cruciate disease in dogs is attempting to atone for the effects of the abundantly expressed pro-inflammatory cytokines.

\subsection{Cytokines involved in $T h_{1}$ and $T h_{2}$ differentiation}

As stated previously, cellular and humoral immune responses are orchestrated by subsets of Th cells via their cytokines. IFN- $\gamma$, IL-2 and IL-12 are the key molecules for initiating cell-mediated immune responses, while IL-4 and IL-10 initiate humoral immunity (Rook, 1993). $\mathrm{Th}_{1}$ cytokines inhibit the differentiation of $\mathrm{Th}_{2}$ subsets and vice versa (Rook, 1993).

In human RA, current paradigms suggest that the cytokine balance is skewed in favor of a cellular immune response ( $\mathrm{Th}_{1}$-type) (Kanik et al., 1998; Katsikis et al., 1994; Park et al., 2001; Firestein, 2003). Synovial T cells isolated from patients with RA produce IFN- $\gamma$ and IL-12 after in vitro stimulation (Morita et al., 1998). In addition, gene expression of IFN- $\gamma$ is detected in SF cells of human patients with RA, but not that of IL-4 (Bucht et al., 1996). Recent research in canine CrCL rupture, showed conflicting results. Hegemann et al. (2005) found higher expression of $\mathrm{Th}_{1}$ cytokines (IL-2 and IFN- $\gamma$ ) and an almost nonexistent IL-4 expression in the SF cells, possibly implicating a dominance of cellular immunity. In contrast, research by de Bruin et al. (2007c) revealed a low prevalence of IFN- $\gamma$ expression and a relatively moderate expression of IL-10 which the authors found to be suggestive for a Th2 dominance in joints with cruciate disease, favoring a humoral immune response (de Bruin et al., 2007c).

\section{Proteolytic tissue degradation}

Dogs with CrCL rupture typically have increased levels of glycoaminoglycans in their SF, indicating increased degradation of joint tissue (Arican et al., 1994). Moreover, the joint tissues of cruciate patients (synovial tissue, cartilage and CrCL) express many degradative enzymes including MMPs, cathepsins and tartrate-resistant acid phosphatase (TRAP) (Spreng et al., 1999; Muir et al., 2002; Muir et al., 2005a). 
MMPs play an important role in normal tissue remodeling. MMPs are a family of zinc-dependent endopeptidases that have the combined ability to degrade all components of the extracellular matrix (Brinckerhoff, 1991). Based on their domain structure and substrate-specificities, MMPs can be divided into subclasses (collagenases, gelatinases, stromelysins and membrane type MMP). Collagenases and stromelysin play an important role in the MMP cascade. Collagenases are capable of degrading native collagens. For example, collagenase-1 (MMP-1) preferentially cleaves collagen type III, collagenase-2 (MMP-8) has a higher specificity for collagen type I, and collagenase-3 (MMP-13) for collagen type II (Martel-Pelletier et al., 2001). Stromelysin (MMP-3) has a broader substrate-specificity that includes proteoglycans, elastin, laminin, fibronectin, but also collagen type IV, V, VII, IX, XI and denatured collagen type I (MartelPelletier et al., 2001). Inactivation of the MMPs involves specific inhibitors, called the tissue inhibitor of metalloproteinases (TIMP-1, TIMP-2, TIMP-3 and TIMP-4) that are abundantly present in all body fluids. Dysregulation of the MMPs, their inhibitors, or both, can be a key event in shifting the MMP cascade from physiologic to pathologic conditions (Martel-Pelletier et al., 2001). There is accumulating evidence that MMPs play a prominent role in degradation of tendons, ligaments and articular cartilage in various arthropathies (Pelletier et al., 1993b; Muir et al., 2005a; MartelPelletier et al., 2001; Dalton et al., 1995). In various joint diseases, an imbalance between MMPs and their inhibitors exists, in favor of the MMPs. So once activated, MMPs cannot be sufficiently counteracted (Lohmander et al., 1993, 1994; Tchetverikov et al., 2005).

In a CrCL transection model in rabbits, rapid loss of collagen matrix was associated with a significant increase in collagenase activity (Amiel et al., 1989). Moreover, synovectomy of the synovial sheath around the $\mathrm{CrCL}$ in rabbits (thereby exposing the $\mathrm{CrCL}$ to the intra-articular environment), caused an increase in collagenase activity in the ligament (Amiel et al., 1990). An experimentally induced partial $\mathrm{CrCL}$ injury in sheep, through transection of the caudolateral band of the CrCL, caused a significant increase in MMP-13 mRNA levels in the uninjured craniomedial band of this ligament 6 weeks following injury (Lo et al., 2003). Importantly, no increase of this collagenase was seen in the $\mathrm{CaCL}$, suggesting that the observed changes were ligament specific (Lo et al., 2003). Increases of these enzymes are suggestive of matrix remodeling and possibly of degradation of the CrCL. An in vitro study examining the effect of mechanical stretch injury to human ligament cells on the gelatinase (MMP-2) production and activity demonstrated that more proMMP-2 was produced in ACL fibroblasts compared with medial collateral ligament fibroblasts (Zhou et al., 2005). In addition, more pro-MMP- 2 was converted into active MMP-2 in injured ACL fibroblasts compared with medial collateral ligament fibroblasts (Zhou et al., 2005). The ACL fibroblasts also maintained a higher level of active MMP-2 after injury. In fact, injured ACL fibroblasts released almost 20 times more active MMP2 than injured medial collateral ligament fibroblasts (Zhou et al., 2005). Taken together, these studies suggest that after injury, the CrCL accumulates very high levels of pro-MMPs and active MMPs which could result in ligament degradation and absorption. This might explain why many stretch or partial CrCL injuries eventually evolve into complete CrCL ruptures in both humans and animals.

Matrix metalloproteinase levels have been studied in the SF of human patients with ACL injury. Increased levels of pro-MMP-1, pro-MMP-3 and TIMP-1 were found by ELISA in the SF within hours after ACL injury (Lohmander et al., 1993, 1994; Tchetverikov et al., 2005). Two weeks after injury, a significant increase of active MMP-1 and decrease in TIMP-1 was noticed (Tchetverikov et al., 2005). This could mean that the amount of inhibitor present in the injured joint is insufficient to inhibit the activated MMP-1 (Lohmander et al., 1993, 1994; Tchetverikov et al., 2005). The levels of pro-MMP-3 reached a maximum several weeks after injury whereafter it declined. The level did remain elevated for several years, compared with levels in uninjured knee joints (Lohmander et al., 1993, 1994). The level of active MMP-3, however, was not increased compared with healthy joints, for at least 4 years after injury (Tchetverikov et al., 2005). These studies show that proteolytic activity remains high after ACL injury. Stromelysin activity has also been studied in the SF, cartilage, synovial tissue and remnants of $\mathrm{CrCL}$ of dogs with CrCL rupture (Fujita et al., 2006; Spreng et al., 1999). Cartilage explants from CrCL deficient stifle joints produced more stromelysin than cartilage from normal stifle joints (Spreng et al., 1999). In addition, explants of the remnants of ruptured CrCL showed a tendency to produce higher levels of stromelysin than normal CrCLs. Higher MMP-3 was detected in the SF of dogs with CrCL rupture compared with normal stifle joints (Fujita et al., 2006). Synovial tissue explants from cruciate deficient stifles, however, produced less stromelysin than normal synovial tissue (Spreng et al., 1999). This suggests that stromelysin is produced 
locally in the degenerative tissues (Spreng et al., 1999). Recently, mRNA expression of MMP was examined in CrCL cells and SF cells from cruciate deficient dogs and dogs with intact CrCLs (Muir et al., 2005a). No MMP expression was found in the $\mathrm{CrCL}$ and SF cells of normal young small breed dogs. The expression of stromelysin was significantly increased in intact $\mathrm{CrCL}$ cells of older and larger breed dogs compared with intact CrCL cells from young, small breed dogs. MMP1 expression was also found in some of the CrCL cells from these two groups. Expression of MMP-1 and MMP-2 was significantly increased in the SF cells of these large breed dogs compared to the small breed dogs. Expression of MMP in CrCL and SF cells of these older, large breed dogs suggests that there is a higher matrix turnover and/or, possibly, a degenerative process in the cruciate ligaments. These results relate to the histopathological findings of Vasseur et al. (1985), who found degenerative changes in the intact CrCL earlier in larger breed dogs than in small breed dogs. In dogs with cruciate disease, gene expression of MMP-1, -2, -3, -9 and -13 was detected in both the CrCL and SF cells, in particular the gelatinases (MMP-2 and -9) (Muir et al., 2005a). Significant higher levels of MMP-2 and -9 have also been detected in the SF of dogs with cruciate disease (Coughlan et al., 1998; Volk et al., 2003). Recently, the presence of MMP-1 and TIMP-2 in the SF of dogs with CrCL rupture and dogs with intact $\mathrm{CrCL}$ has been investigated (Salinardi et al., 2006). This study found elevated levels of MMP-1 and reduced levels of TIMP-2 in the SF of cruciate deficient dogs (Salinardi et al., 2006); MMP-1 levels were decreased in the sera of dogs with cruciate disease (Salinardi et al., 2006). This implies that MMP-1 is either expressed at a lower level systemically and at a higher level within the joint, or that it leaves the systemic circulation and enters the damaged joints in dogs with CRCL rupture. The reason for this is unknown (Salinardi et al., 2006).

The synovial tissue of dogs with cruciate disease also express other collagenolytic enzymes, for instance cathepsins and TRAP (Muir et al., 2002, 2005a,b). Cathepsins are cysteine proteinases that are able to cleave the N-terminal end of the collagen triple helix, creating access for other proteolytic enzymes (Kafienah et al., 1998). TRAP are a class of metalloenzymes that catalyze the hydrolysis of various phosphate esters and anhydrides under acidic reaction conditions (Oddie et al., 2000). TRAP positive cells, such as the synovial macrophage-like cells, can secrete various proteinases and generate reactive oxygen species, thus able to cleave the triple helix of collagen (Halleen et al., 1999; Tsuboi et al., 2003). Both cathepsin and TRAP are products of activated macrophages and synovial fibroblasts (Hou et al., 2001). In dogs with CrCL rupture, localization of cathepsin $\mathrm{K}$ and TRAP in CrCL cells correlated with cruciate ligament injury (Muir et al., 2002). However, studying the gene expression of these collagenolytic enzymes in SF and CrCL cells, revealed that only TRAP and cathepsin S were present in dogs with cruciate disease compared with normal joints (Muir et al., 2005a). In contrast, cathepsin K mRNA expression was found in intact $\mathrm{CrCL}$ and their corresponding SF cells, and in cells isolated from cruciate deficient stifle joints (Muir et al., 2005a), which would indicate that cathepsin $\mathrm{K}$ is important in normal daily matrix turnover. A limiting factor in these three studies is that they only examined stifle joints with cruciate disease and no other joint pathology. It is therefore risky to conclude that these enzymes correlate with cruciate injury since they may correlate with inflammatory changes in general. A very recent study compared the presence of TRAP and cathepsin $\mathrm{K}$ in ruptured and intact human ACL with ruptured and intact canine CrCL (Barrett et al., 2005). Interestingly, a significant higher amount of TRAP and cathepsin $\mathrm{K}$ positive cells were found in the injured canine CrCL than in the damaged human ACL, suggesting a different proteolytic pathology in canine CrCL (Barrett et al., 2005).

Production of MMPs, cathepsins and TRAP at sites of inflammation potentially contributes to matrix degradation. More importantly, it remains to be determined whether changes in these proteolytic enzymes initiate cruciate disease in dogs or whether they are the result of the disease progression.

\section{Conclusions}

Many veterinarians have endeavored to unravel the multifactorial ethiopathogeneis of spontaneous CrCL rupture in dogs, but data are incomplete and the mechanisms that are responsible for the degenerative changes in the CrCL remain unclear. One of the major limitations in most investigations is that most studies in CrCL disease have focused on the affected stifle joint after rupture, the end stage of the disease.

Immune-mediated mechanisms could play a role in the induction of joint inflammation. Indeed, the cruciate ligaments can act as self-antigens in cases of damage due to their extra-synovial position and therefore seclusion from immune surveillance (Osborne et al., 1995; Kobayashi et al., 2006). The prevalence and relevance of humoral and cellular reactivity to collagen type I in dogs with cruciate disease is not yet clear. 
The exact role of pro-inflammatory cytokines, antiinflammatory cytokines, chemokines, growth factors and degradative enzymes in he initiation of cruciate disease in dogs remains unclear. Determining the initial inflammatory process, however, could implicate that by targeting this process, one might be able to prevent $\mathrm{CrCL}$ impairment in the contralateral stifle joint in the future.

\section{References}

Akahoshi, T., Endo, H., Kondo, H., Kashiwazaki, S., Kasahara, T., Mukaida, N., Harada, A., Matsushima, K., 1994. Essential involvement of interleukin-8 in neutrophil recruitment in rabbits with acute experimental arthritis induced by lipopolysaccharide and interleukin-1. Lymphokine Cytokine Res. 13 (2), 113-116.

Alm, A., Strömberg, B., 1974. Vascular anatomy of the patellar and cruciate ligaments. A microangiographic and histologic investigation in the dog. Acta. Chir. Scand. Suppl. 445, 25-35.

Amiel, D., Ishizue, K.K., Harwood, F.L., Kitabayashi, L., Akeson, W.H., 1989. Injury of the anterior cruciate ligament: the role of collagenase in ligament degeneration. J. Orthop. Res. 7 (4), 486-493.

Amiel, D., Billings E.Jr., Harwood, F.L., 1990. Collagenase activity in anterior cruciate ligament: protective role of the synovial sheath. J. Appl. Physiol. 69 (3), 902-906.

Arend, W.P., 1993. Interleukines and arthritis: Il-1 antagonism in inflammatory arthritis. Lancet $341,155-156$.

Arend, W.P., Welgus, H.G., Thompson, R.C., Eisenberg, S.P., 1990. Biological properties of recombinant human monocyte-derived interleukin 1 receptor antagonist. J. Clin. Invest. 85 (5), 1694-1697.

Arican, M., Carter, S.D., Bennett, D., May, C., 1994. Measurement of glycosaminoglycans and keratan sulphate in canine arthropathies. Res. Vet. Sci. 56 (3), 290-297.

Arnoczky, S.P., Marshall, J.L., 1981. Pathomechanics of cruciate and meniscal injuries. In: Bojrab, M.J. (Ed.), Pathofysiology of Small Animal Surgery. Lea \& Febiger, Philadelphia, pp. 590-603.

Arnoczky, S.P., Rubin, R.M., Marshall, J.L., 1979. Microvasculature of the cruciate ligaments and its response to injury. An experimental study in dogs. J. Bone Joint Surg. Am. 61 (8), 1221-1229.

Baggiolini, M., Dewald, B., Moser, B., 1994. Interleukin-8 and related chemotactic cytokines: CXC and CC chemokines. Adv. Immunol. $55,97-179$.

Banchereau, J., Rybak, M., 1994. Interleukin-4. In: Thomson, A. (Ed.), The Cytokine Handbook. Academic Press, London, pp. 99-126.

Bari, A.S., Carter, S.D., Bell, S.C., Morgan, K., Bennett, D., 1989. Anti-type II collagen antibody in naturally occurring canine joint diseases. Br. J. Rheumatol. 28 (6), 480-486.

Barrett, J.G., Hao, Z., Graf, B.K., Kaplan, L.D., Heiner, J.P., Muir, P., 2005. Inflammatory changes in ruptured canine cranial and human anterior cruciate ligaments. Am. J. Vet. Res. 66 (12), 2073-2080.

Baxter, R.C., 2000. Insulin-like growth factor (IGF)-binding proteins: interactions with IGFs and intrinsic bioactivities. Am. J. Physiol. Endocrinol. Metab. 278 (6), E967-976.

Bennett, D., Tennant, B., Lewis, D.G., Baughan, J., May, C., Carter, S., 1988. A reappraisal of anterior cruciate disease in the dog. J. Small Anim. Pract. 29, 275-297.
Bertazzolo, N., Punzi, L., Stefani, M.P., Cesaro, G., Pianon, M., Finco, B., Todesco, S., 1994. Interrelationships between interleukin (IL)1, IL-6 and IL-8 in synovial fluid of various arthropathies. Agents Actions 41 (1-2), 90-92.

Blom, A.B., van Lent, P.L., Holthuysen, A.E., van der Kraan, P.M., Roth, J., van Rooijen, N., van den Berg, W.B., 2004. Synovial lining macrophages mediate osteophyte formation during experimental osteoarthritis. Osteoarthritis Cartilage 12 (8), 627-635.

Bogdan, C., Vodovotz, Y., Nathan, C., 1991. Macrophage deactivation by interleukin 10. J. Exp. Med. 174 (6), 1549-1555.

Bolon, B., Campagnuolo, G., Zhu, L., Duryea, D., Zack, D., Feige, U., 2004. Interleukin-1beta and tumor necrosis factor-alpha produce distinct, time-dependent patterns of acute arthritis in the rat knee. Vet Pathol. 41 (3), 235-243.

Borzi, R.M., Mazzetti, I., Macor, S., Silvestri, T., Bassi, A., Cattini, L., Facchini, A., 1999. Flow cytometric analysis of intracellular chemokines in chondrocytes in vivo: constitutive expression and enhancement in osteoarthritis and rheumatoid arthritis. Fed. Eur. Biochem. Soc. Lett. 455, 238-242.

Brennan, F.M., Maini, R.N., Feldmann, M., 1995. Cytokine expression in chronic inflammatory disease. Br. Med. Bull. 53, 368-384.

Brinckerhoff, C.E., 1991. Joint destruction in arthritis: metalloproteases and inhibitors in arthritic diseases. Arthritis Rheum. 34, 1073-1075.

Bucht, A., Larsson, P., Weisbrot, L., Thorne, C., Pisa, P., Smedegard, G., Keystone, E.C., Gronberg, A., 1996. Expression of interferongamma (IFN-gamma), IL-10, IL-12 and transforming growth factor-beta (TGF-beta) mRNA in synovial fluid cells from patients in the early and late phases of rheumatoid arthritis (RA). Clin. Exp. Immunol. 103 (3), 357-367.

Cameron, M.L., Fu, F.H., Paessler, H.H., Schneider, M., Evans, C.H., 1994. Synovial fluid cytokine concentrations as possible prognostic indicators in the ACL-deficient knee. Knee Surg. Sports Traumatol. Arthrosc. 2 (1), 38-44.

Cameron, M., Buchgraber, A., Passler, H., Vogt, M., Thonar, E., Fu, F., Evans, C.H., 1997. The natural history of the anterior cruciate ligament-deficient knee. Changes in synovial fluid cytokine and keratan sulfate concentrations. Am. J. Sports Med. 25 (6), 751-754.

Canete, J.D., Martinez, S.E., Farres, J., Sanmarti, R., Blay, M., Gomez, A., Salvador, G., Munoz-Gomez, J., 2000. Differential Th1/Th2 cytokine patterns in chronic arthritis: interferon gamma is highly expressed in synovium of rheumatoid arthritis compared with seronegative spondyloarthropathies. Ann. Rheum. Dis. 59 (4), 263-268.

Cannon, G.W., Pincus, S.H., Emkey, R.D., Denes, A., Cohen, S.A., Wolfe, F., Saway, P.A., Jaffer, A.M., Weaver, A.L., Cogen, L., Schindler, J.P., 1989. Double-blind trial of recombinant gammainterferon versus placebo in the treatment of rheumatoid arthritis. Arthritis Rheum. 32 (8), 964-973.

Cannon, G.W., Emkey, R.D., Denes, A., Cohen, S.A., Saway, P.A., Wolfe, F., Jaffer, A.M., Weaver, A.L., Manaster, B.J., McCarthy, K.A., 1993. Prospective 5-year followup of recombinant interferongamma in rheumatoid arthritis. J Rheumatol. 20 (11), 1867-1873.

Caron, J.P., Fernandes, J.C., Martel-Pelletier, J., Tardif, G., Mineau, F., Geng, C., Pelletier, J.P., 1996. Chondroprotective effect of intraarticular injections of interleukin-1 receptor antagonist in experimental osteoarthritis: suppression of collagenase-1 expression. Arthritis Rheum. 39, 1535-1544.

Carter, S.D., Barnes, A., Gilmore, W.H., 1999. Canine rheumatoid arthritis and inflammatory cytokines. Vet Immunol. Immunopathol. 69, 201-214. 
Cenci, E., Romani, L., Mencacci, A., Spaccapelo, R., Schiaffella, E., Puccetti, P., Bistoni, F., 1993. Interleukin-4 and interleukin-10 inhibit nitric oxide-dependent macrophage killing of Candida albicans. Eur. J. Immunol. 23 (5), 1034-1038.

Cheon, H., Yu, S.J., Yoo, D.H., Chae, I.J., Song, G.G., Sohn, J., 2002. Increased expression of pro-inflammatory cytokines and metalloproteinase-1 by TGF-beta1 in synovial fibroblasts from rheumatoid arthritis and normal individuals. Clin. Exp. Immunol. 127 (3), 547-552.

Chrisman, O.D., Fessell, J.M., Southwick, W.D., 1965. Experimental production of synovitis and marginal articular exostoses in the knee joints of dogs. Yale J. Biol. Med. 37, 409-412.

Chu, Q., Lopez, M., Hayashi, K., Ionescu, M., Billinghurst, R.C., Johnson, K.A., Poole, A.R., Markel, M.D., 2002. Elevation of a collagenase generated type II collagen neoepitope and proteoglycan epitopes in synovial fluid following induction of joint instability in the dog. Osteoarthritis Cartilage 10 (8), 662-669.

Cole, P., Rabasseda, X., 2004. The soluble tumor necrosis factor receptor etanercept: a new strategy for the treatment of autoimmune rheumatic disease. Drugs Today (Barc) 40 (4), 281-324.

Cooke, T.D., 1980. Immune deposits in osteoarthritis cartilage-their relationship to synovitis and disease site and pattern. Semin. Arthritis Rheum. 9 (Suppl.), 109-110.

Cooke, T.D., Hurd, E.R., Ziff, M., Jasin, H.E., 1972. The pathogenesis of chronic inflammation in experimental antigen-induced arthritis. II. Preferential localization of antigan-antibody complexes to collagenous tissues. J. Exp. Med. 135, 323-338.

Cope, A.P., Aderka, D., Doherty, M., Engelmann, H., Gibbons, D., Jones, A.C., Brennan, F.M., Maini, R.N., Wallach, D., Feldmann, F., 1992. Increased levels of soluble tumor necrosis factor receptors in the sera and synovial fluid of patients with rheumatic diseases. Arthritis Rheum. 35, 1160-1169.

Coughlan, A.R., Robertson, D.H., Bennett, D., May, C., Beynon, R.J., Carter, S.D., 1998. Matrix metalloproteinases 2 and 9 in canine rheumatoid arthritis. Vet. Rec. 143 (8), 219-223.

Courtenay, J.S., Dallman, M.J., Dayan, A.D., Martin, A., Mosedale, B., 1980. Immunisation against heterologous type II collagen induces arthritis in mice. Nature 283 (5748), 666-668.

Cush, J.J., Splawski, J.B., Thomas, R., McFarlin, J.E., Schulze-Koops, H., Davis, L.S., Fujita, K., Lipsky, P.E., 1995. Elevated interleukin-10 levels in patients with rheumatoid arthritis. Arthritis Rheum. 38 (1), 96-104.

Dalton, S., Cawston, T.E., Riley, G.P., Bayley, I.J., Hazleman, B.L., 1995. Human shoulder tendon biopsy samples in organ culture produce procollagenase and tissue inhibitor of metalloproteinases. Ann. Rheum. Dis. 54 (7), 571-577.

Davis, L.S., Cush, J.J., Schulze-Koops, H., Lipsky, P.E., 2001. Rheumatoid synovial CD4+ $\mathrm{T}$ cells exhibit a reduced capacity to differentiate into IL-4-producing T-helper-2 effector cells. Arthritis Res. 3 (1), 54-64.

de Bruin, T., de Rooster, H., van Bree, H., Cox, E., 2005. Interleukin-8 mRNA expression in synovial fluid of canine stifle joints with osteoarthritis. Vet. Immunol. Immunopathol. 108 (3-4), 387-397.

de Bruin, T., de Rooster, H., van Bree, H., Cox, E., 2007a. Evaluation of anticollagen type I antibody titers in synovial fluid of both stifle joints and the left shoulder joint of dogs with unilateral cranial cruciate disease. Am. J. Vet. Res. 68 (3), 283-289.

de Bruin, T., de Rooster, H., van Bree, H., Waelbers, T., Cox, E., 2007b. Lymphocyte proliferation to collagen type I in dogs. J. Vet. Med. A Physiol. Pathol. Clin. Med. 54 (6), 292-296.

de Bruin, T., de Rooster, H., van Bree, H., Cox, E., 2007c. Cytokine mRNA expression in synovial fluid of affected and contralateral stifle joints and the left shoulder joint in dogs with unilateral disease of the stifle joint. Am. J. Vet. Res. 68 (9), 953-961.

de Rooster, H., Cox, E., van Bree, H., 2000. Prevalence and relevance of antibodies to type-I and -II collagen in synovial fluid of dogs with cranial cruciate ligament damage. Am. J. Vet. Res. 61 (11), 1456-1461.

Deleuran, B., Lemche, P., Kristensen, M., Chu, C.Q., Field, M., Jensen, J., Matsushima, K., Stengaard-Pedersen, K., 1994a. Localisation of interleukin 8 in the synovial membrane, cartilagepannus junction and chondrocytes in rheumatoid arthritis. Scand. J. Rheumatol. 23 (1), 2-7.

Deleuran, B., Iversen, L., Kristensen, M., Field, M., Kragballe, K., Thestrup-Pedersen, K., Stengaard-Pedersen, K., 1994b. Interleukin-8 secretion and 15-lipoxygenase activity in rheumatoid arthritis: in vitro anti-inflammatory effects by interleukin-4 and interleukin-10, but not by interleukin-1 receptor antagonist protein. Br. J. Rheumatol. 33 (6), 520-525.

Doverspike, M., Vasseur, P.B., Walls, C.M., 1993. Contralateral cranial cruciate ligament rupture: Incidence in 114 dogs. J. Am. Anim. Hosp. Assoc. 29, 167-170.

Elkins, A.D., Pechman, R., Kearney, M.Y., Herron, M., 1991. A retrospective study evaluating the degree of degenerative joint disease in the stifle joint in dogs following surgical repair of anterior cruciate ligament rupture. J. Am. Anim. Hosp. Assoc. 27, 533-540.

Emshoff, R., Puffer, P., Rudisch, A., Gassner, R., 2000. Temporomandibular joint pain: relationship to internal derangement type, osteoarthrosis, and synovial fluid mediator level of tumor necrosis factor-alpha. Oral Surg. Oral Med. Oral Pathol. Oral Radiol. Endod. 90 (4), 442-449.

Endo, H., Akahoshi, T., Takagishi, K., Kashiwazaki, S., Matsushima, K., 1991. Elevation of interleukin-8 (IL-8) levels in joint fluids of patients with rheumatoid arthritis and the induction by IL- 8 of leukocyte infiltration and synovitis in rabbit joints. Lymphokine Cytokine Res. 10 (4), 245-252.

Evans, C.H., Mazzocchi, R.A., Nelson, D.D., Rubash, H.E., 1984. Experimental arthritis induced by intraarticular injection of allogenic cartilaginous particles into rabbit knees. Arthritis Rheum. 27 (2), 200-207.

Faldyna, M., Zatloukal, J., Leva, L., Necas, A., Toman, M., 2004a. Lymphocyte subsets in synovial fluid from clinically healthy joints of dogs. Acta. Vet. Brno. 73, 73-78.

Faldyna, M., Zatloukal, J., Leva, L., Kohout, P., Necas, A., Toman, M., 2004b. Lymphocyte subsets in synovial fluid of dogs with spontaneous rupture of the cranial cruciate ligament. Acta. Vet. Brno. 73, 79-84.

Felsburg, P.J., 2002. Overview of immune system development in the dog: comparison with humans. Hum. Exp. Tox. 21, 487-492.

Fernandes, J.C., Caron, J.P., Martel-Pelletier, J., Jovanovic, D., Mineau, F., Tardif, G., Otterness, I.G., Pelletier, J.P., 1997. Effects of tenidap on the progression of osteoarthritic lesions in a canine experimental model. Suppression of metalloprotease and interleukin-1 activity. Arthritis Rheum. 40 (2), 284-294.

Fernandez, B.R., 1991. Soluble cytokine receptors: their role in immunoregulation. FASEB J. 5, 2567-2574.

Fernihough, J.K., Billingham, M.E., Cwyfan-Hughes, S., Holly, J.M., 1996. Local disruption of the insulin-like growth factor system in the arthritic joint. Arthritis Rheum. 39 (9), 1556-1565.

Fernihough, J.K., Innes, J.F., Billingham, M.E., Holly, J.M., 2003. Changes in the local regulation of insulin-like growth factors I and II and insulin-like growth factor-binding proteins in osteoarthritis 
of the canine stifle joint secondary to cruciate ligament rupture. Vet Surg. 32 (4), 313-323.

Firestein, G.S., 2003. Envolving concepts of rheumatoid arthritis. Nature 423, 356-361.

Firestein, G.S., Boyle, D.L., Yu, C., Paine, M.M., Whisenand, T.D., Zvaifler, N.J., Arend, W.P., 1994. Synovial interleukin-1 receptor antagonist and interleukin-1 balance in rheumatoid arthritis. Arthritis Rheum. 37 (5), 644-652.

Fujikawa, Y., Shingu, M., Torisu, T., Masumi, S., 1995. Interleukin-1 receptor antagonist production in cultured synovial cells from patients with rheumatoid arthritis and osteoarthritis. Ann. Rheum. Dis. 54 (4), 318-320.

Fujita, Y., Hara, Y., Nezu, Y., Schulz, K.S., Tagawa, M., 2006. Proinflammatory cytokine activities, matrix metalloproteinase-3 activity, and sulfated glycosaminoglycan content in synovial fluid of dogs with naturally acquired cranial cruciate ligament rupture. Vet. Surg. 35 (4), 369-376.

Furuzawa, C.J., Alocer, V.J., 1999. Interleukin-8, Interleukin-10, intercellular adhesion molecule-1 and vascular cell adhesion molecule-1 expression levels are higher in synovial tissue from patients with rheumatoid arthritis than in osteoarthritis. Scand. J. Immunol. 50, 215-222.

Galloway, R.H., Lester, S.J., 1995. Histopathological evaluation of canine stifle joint synovial membrane collected at the time of repair of cranial cruciate ligament rupture. J. Am. Anim. Hosp. Assoc. 31 (4), 289-294.

Ghezzi, P., Dinarello, C.A., 1988. Il-1 induces Il-1 III. Specific inhibition of Il-1 production bij IFN- $\gamma$ J. Immunol. 140, 42384244.

Goldberg, V.M., Burstein, A., Dawson, M., 1982. The influence of an experimental immune synovitis on the failure mode and strength of the rabbit anterior cruciate ligament. J. Bone Joint Surg. Am. 64 (6), 900-906.

Goldring, M.B., 1999. The role of cytokines as inflammatory mediators in osteoarthritis: lessons from animal models. Connect Tissue Res. 40, 1-11.

Halleen, J.M., Räisänen, S., Salo, J.J., Reddy, S.V., Roodman, G.D., Teuvo, A., Hentunen, T.A., Lehenkari, P.P., Kaija, H., Vihko, P., Väänänen, H.K., 1999. Intracellular fragmentation of bone resorption products bij reactive oxygen species generated by osteoclatic tartrate-resistant acid phosphatase. J. Biol. Chem. 274, 2290722910.

Hardingham, Bayliss, M.T., Rayan, V., Noble, D.P., 1992. Effects of growth factors and cytokines on proteoglycan turnover in articular cartilage. Br. J. Rheumatol. 31 (Suppl. 1), 1-6.

Hay, C.W., Chu, Q., Budsberg, S.C., Clayton, M.K., Johnson, K.A., 1997. Synovial fluid interleukin 6, tumor necrosis factor, and nitric oxide values in dogs with osteoarthritis secondary to cranial cruciate ligament rupture. Am. J. Vet. Res. 58 (9), 1027-1032.

Hegemann, N., Wondimu, A., Kohn, B., Brunnberg, L., Schmidt, M.F., 2005. Cytokine profile in canine immune-mediated polyarthritis and osteoarthritis. Vet. Comp. Orthop. Traumatol. 18 (2), 67-72.

Hewicker, T.M., Carter, S.D., Bennett, D., 1999. Immunocytochemical demonstration of lymphocyte subsets and MHC class II antigen axpression in synovial membranes from dogs with rheumatoid arthritis and degenerative joint disease. Vet Immuno. Immunopathol. 67, 341-357.

Hirano, T., 1994. Interleukin-6. In: Thomson, A. (Ed.), The Cytokine Handbook. Academic Press, London, pp. 145-168.

Hirota, K., Akahoshi, T., Endo, H., Kondo, H., Kashiwazaki, S., 1992. Production of interleukin 8 by cultured synovial cells in response to interleukin 1 and tumor necrosis factor. Rheumatol. Int. 12, 13-16.
Holt, I., Cooper, R.G., Denton, J., Meager, A., Hopkins, S.J., 1992. Cytokine inter-relationships and their association with disease activity in arthritis. Br. J. Rheumatol. 31, 725-733.

Hopper, P.E., 1993. Immune-mediated joint diseases. In: Slatter, D.H (Ed.), Textbook of Small Animal Surgery. Saunders W.B., Philadelphia, pp. 1928-1937.

Hou, W.S., Li, Z., Gordon, R.E., Chan, K., Klein, M.J., Levy, R., Keysser, M., Keyszer, G., Bromme, D., 2001. Cathepsin k is a critical protease in synovial fibroblast-mediated collagen degradation. Am. J. Pathol. 159 (6), 2167-2177.

Hulkower, K.I., Wertheimer, S.J., Levin, W., Coffey, J.W., Anderson, C.M., Chen, T., DeWitt, D.L., Crowl, R.M., Hope, W.C., Morgan, D.W., 1994. Interleukin-1 beta induces cytosolic phospholipase A2 and prostaglandin $\mathrm{H}$ synthase in rheumatoid synovial fibroblasts. Evidence for their roles in the production of prostaglandin E2. Arthritis Rheum. 37, 653-661.

Innes, J.F., Sharif, M., Barr, A.R., 1998. Relations between biochemical markers of osteoarthritis and other disease parameters in a population of dogs with naturally acquired osteoarthritis of the genual joint. Am. J. Vet. Res. 59, 1530-1536.

Irie, K., Uchiyama, E., Iwaso, H., 2003. Intraarticular inflammatory cytokines in acute anterior cruciate ligament injured knee. Knee 10, 93-96.

Isomaki, P., Luukkainen, R., Saario, R., Toivanen, P., Punnonen, J., 1996. Interleukin-10 functions as an antiinflammatory cytokine in rheumatoid synovium. Arthritis Rheum. 39, 386-395.

Jasin, H.E., 1985. Autoantibody specificities of immune complexes sequestered in articular cartilage of patients with rheumatoid arthritis and osteoarthritis. Arthritis Rheum. 28, 832-840.

Jin, D., Zhang, L., Zheng, J., Zhao, Y., 2008. The inflammation $\mathrm{Th}_{17}$ subset in immunity against self and non-self antigens. Autoimmunity 42 (2), 154-162.

Jones, J.L., Clemmons, D.R., 1995. Insulin-like growth factors and their binding proteins: biological action. Endocr. Rev. 16, 3-38.

Joosten, L.A., Helsen, M.M., van de Loo, F.A., van den Berg, W.B., 1996. Anticytokine treatment of established type II collageninduced arthritis in DBA/1 mice. A comparative study using anti-TNF alpha, anti-IL-1 alpha/beta, and IL-1Ra. Arthritis Rheum. 39, 797-809.

Kafienah, W., Brömme, D., Buttle, D.J., Croucher, L.J., Hollander, A.P., 1998. Human cathepsin K cleaves native type I and II collagens at the N-terminal end of the triple helix. Biochem. J. 331 (Pt 3), 727-732.

Kaneko, S., Satoh, T., Chiba, J., Ju, C., Inoue, K., Kagawa, J., 2000 Interleukin-6 and interleukin-8 levels in serum and synovial fluid of patients with osteoarthritis. Cytokines Cell. Mol. Ther. 6 (2), 71-79.

Kaneyama, K., Segami, N., Nishimura, M., Suzuki, T., Sato, J., 2002. Importance of proinflammatory cytokines in synovial fluid from 121 joints with temporomandibular disorders. Br. J. Oral. Maxillofac. Surg. 40 (5), 418-423.

Kaneyama, K., Segami, N., Sun, W., Sato, J., Fujimura, K., 2005. Analysis of tumor necrosis factor-alpha, interleukin-6, interleukin-1beta, soluble tumor necrosis factor receptors I and II, interleukin-6 soluble receptor, interleukin-1 soluble receptor type II, interleukin-1 receptor antagonist, and protein in the synovial fluid of patients with temporomandibular joint disorders. Oral Surg. Oral Med. Oral Pathol. Oral Radiol. Endod. 99 (3), 276-284.

Kanik, K.S., Hagiwara, E., Yarboro, C.H., Schumacher, H.R., Wilder, R.L., Klinman, D.M., 1998. Distinct patterns of cytokine secretion characterize new onset synovitis versus chronic rheumatoid arthritis. J. Rheumatol. 25, 16-22. 
Katsikis, P.D., Chu, C.Q., Brennan, F.M., Maini, R.N., Feldmann, M., 1994. Immunoregulatory role of interleukin 10 in rheumatoid arthritis. J. Exp. Med. 179, 1517-1527.

Kelley, K.M., Oh, Y., Gargosky, S.E., Gucev, Z., Matsumoto, T., Hwa, V., Ng, L., Simpson, D.M., Rosenfeld, R.G., 1996. Insulin-like growth factor-binding proteins (IGFBPs) and their regulatory dynamics. Int. J. Biochem. Cell Biol. 28 (6), 619-637.

Kerr, L.D., Miller, D.B., Matrisian, L.M., 1990. TGF-beta 1 inhibition of transin/stromelysin gene expression is mediated through a Fos binding sequence. Cell 61, 267-278.

Kirkham, B., Portek, I., Lee, C.S., Stavros, B., Lenarczyk, A., Lassere, M., Edmonds, J., 1999. Intraarticular variability of synovial membrane histology, immunohistology, and cytokine mRNA expression in patients with rheumatoid arthritis. J. Rheumatol. 26 (4), 777-784.

Klocke, N.W., Snyder, P.W., Widmer, W.R., Zhong, W., McCabe, G.P., Breur, G.J., 2005. Detection of synovial macrophages in the joint capsule of dogs with naturally occurring rupture of the cranial cruciate ligament. Am. J. Vet. Res. 66, 493-499.

Kobayashi, S., Baba, H., Uchida, K., Negoro, K., Sato, M., Miyazaki, T., Nomura, E., Murakami, K., Shimizubata, M., Meir, A., 2006. Microvascular system of anterior cruciate ligament in dogs. J. Orthop. Res. 24, 1509-1520.

Kondo, E., Yasuda, K., Yamanaka, M., Minami, A., Tohyama, H., 2005. Effects of administration of exogenous growth factors on biomechanical properties of the elongation-type anterior cruciate ligament injury with partial laceration. Am. J. Sports Med. 33 (2), 188-196.

Larsen, C.G., Anderson, A.O., Appella, E., Oppenheim, J.J., Matsushima, K., 1989. The neutrophil-activating protein (NAP-1) is also chemotactic for T lymphocytes. Science 243 (4897), 14641466.

Lawrence, D., Bao, S., Canfield, P.J., Allanson, M., Husband, A.J., 1998. Elevation of immunoglobulin deposition in the synovial membrane of dogs with cranial cruciate ligament rupture. Vet. Immunol. Immunopathol. 65 (1), 89-96.

Lee, J., Harwood, F.L., Akeson, W.H., Amiel, D., 1998. Growth factor expression in healing rabbit medial collateral and anterior cruciate ligaments. Iowa Orthop. J. 18, 19-25.

Lemburg, A.K., Meyer-Lindenberg, A., Hewicker-Trautwein, M., 2004. Immunohistochemical characterization of inflammatory cell populations and adhesion molecule expression in synovial membranes from dogs with spontaneous cranial cruciate ligament rupture. Vet. Immunol. Immunopathol. 97 (3-4), 231-240.

Lettesjo, H., Nordstrom, E., Strom, H., Nilsson, B., Glinghammar, B., Dahlstedt, L., Moller, E., 1998. Synovial fluid cytokines in patients with rheumatoid arthritis or other arthritic lesions. Scand. J. Immunol. 48 (3), 286-292.

Lisignoli, G., Toneguzzi, S., Pozzi, C., Piacentini, A., Riccio, M., Ferruzzi, A., Gualtieri, G., Facchini, A., 1999. Proinflammatory cytokines and chemokine production and expression by human osteoblasts isolated from patients with rheumatoid arthritis and osteoarthritis. J. Rheumatol. 26 (4), 791-799.

Lo, I.K., Marchuk, L., Majima, T., Frank, C.B., Hart, D.A., 2003. Medial collateral ligament and partial anterior cruciate ligament transection: mRNA changes in uninjured ligaments of the sheep knee. J. Orthop. Sci. 8 (5), 707-713.

Lohmander, L.S., Hoerrner, L.A., Dahlberg, L., Roos, H., 1993. Stromelysin, tissue inhibitor of metalloproteinases and proteoglycan fragments in human knee joint fluid after injury. J. Rheumatol. 20 (8), 1362-1368.
Lohmander, L.S., Roos, H., Dahlberg, L., Hoerrner, L.A., Lark, M.W., 1994. Temporal patterns of stromelysin-1, tissue inhibitor, and proteoglycan fragments in human knee joint fluid after injury to the cruciate ligament or meniscus. J. Orthop. Res. 12 (1), 21-28.

Lydyard, P., Grossi, C., 1993. Cells involved in immune responses. In: Roitt, I., Brostoff, I., Male, D. (Eds.), Immunology. Mosby, London, pp. 2.1-2.2.

Macias, I., Garcia-Perez, S., Ruiz-Tudela, M., Medina, F., Chozas, N., Giron-Gonzalez, J.A., 2005. Modification of pro- and antiinflammatory cytokines and vascular-related molecules by tumor necrosis factor-a blockade in patients with rheumatoid arthritis. J. Rheumatol. 32 (11), 2102-2108.

Male, D., 1993. Cell migration and inflammation. In: Roitt, I., Brostoff, J., Male, D. (Eds.), Immunology. Mosby, London, pp. 13.1-13.8.

Manicourt, D.H., Poilvache, P., Van Egeren, A., Devogelaer, J.P., Lenz, M.E., Thonar, E.J., 2000. Synovial fluid levels of tumor necrosis factor alpha and oncostatin $M$ correlate with levels of markers of the degradation of crosslinked collagen and cartilage aggrecan in rheumatoid arthritis but not in osteoarthritis. Arthritis Rheum. 43 (2), 281-288.

Marks, P.H., Donaldson, M.L., 2005. Inflammatory cytokine profiles associated with chondral damage in the anterior cruciate ligamentdeficient knee. Arthroscopy 21 (11), 1342-1347.

Martel-Pelletier, J., McCollum, R., Di Battista, J.A., Faure, M.P., Chin, J.A., Fournier, S., Sarfati, M., Pelletier, J.P., 1992. The interleukin-1 receptor in normal and osteoarthritic human articular chondrocytes. Identification as the type I receptor and analysis of binding kinetics and biologic function. Arthritis Rheum. 35, 530540.

Martel-Pelletier, J., Welsch, D.J., Pelletier, J.-P., 2001. Metalloproteases and inhibitors in arthritic diseases. Best Pract. Res. Clin. Rheumatol. 15, 805-829.

Marui, T., Niyibizi, C., Georgescu, H.I., Cao, M., Kavalkovich, K.W., Levine, R.E., Woo, S.L., 1997. Effect of growth factors on matrix synthesis by ligament fibroblasts. J. Orthop. Res. 15, 18-23.

Menzel, J., Steffen, C., Kolarz, G., Eberl, R., Frank, O., Thumb, N., 1976. Demonstration of antibodies to collagen and of collagenanticollagen immune complexes in rheumatoid arthritis synovial fluids. Ann. Rheum. Dis. 35 (5), 446-450.

Menzel, J., Steffen, C., Kolarz, G., Kojer, M., Smolen, J., 1978. Demonstration of anticollagen antibodies in rheumatoid arthritis synovial fluids by 14C-radioimmunoassay. Arthritis Rheum. 21 (2), 243-248.

Miltenburg, A.M., van Laar, J.M., de Kuiper, R., Daha, M.R., Breedveld, F.C., 1991. Interleukin-6 activity in paired samples of synovial fluid. Correlation of synovial fluid interleukin-6 levels with clinical and laboratory parameters of inflammation. Br. J. Rheumatol. 30, 186-189.

Miltenburg, A.M., van Laar, J.M., de Kuiper, R., Daha, M.R., Breedveld, F.C., 1992. T cells cloned from human rheumatoid synovial membrane functionally represent the Th1 subset. Scand. J. Immunol. 35, 603-610.

Moore, K.W., Read, R.A., 1996. Rupture of the cranial cruciate ligament in dogs. Part I. Compend. Contin. Educ. Pract. Vet. 18, 223-233.

Morita, Y., Yamamura, M., Kawashima, M., Harada, S., Tsuji, K., Shibuya, K., Maruyama, K., Makino, H., 1998. Flow cytometric single-cell analysis of cytokine production by CD4+ T cells in synovial tissue and peripheral blood from patients with rheumatoid arthritis. Arthritis Rheum. 41, 1669-1676.

Mosmann, T.R., 1994. Interleukin-10. In: Thomson, A. (Ed.), The Cytokine Handbook. Academic Press, London, pp. 223-237. 
Muir, P., Hayashi, K., Manley, P.A., Colopy, S.A., Hao, Z., 2002. Evaluation of tartrate-resistant acid phosphatase and cathepsin $\mathrm{K}$ in ruptured cranial cruciate ligaments in dogs. Am. J. Vet. Res. 63, 1279-1284.

Muir, P., Danova, N.A., Argyle, D.J., Manley, P.A., Hao, Z., 2005a. Collagenolytic protease expression in cranial cruciate ligament and stifle synovial fluid in dogs with cranial cruciate ligament rupture. Vet. Surg. 34, 482-490.

Muir, P., Schamberger, G.M., Manley, P.A., Hao, Z., 2005b. Localization of cathepsin $\mathrm{K}$ and tartrate-resistant acid phosphatase in synovium and cranial cruciate ligament in dogs with cruciate disease. Vet. Surg. 34, 239-246.

Nalbant, S., Martinez, J.A., Kitumnuaypong, T., Clayburne, G., Sieck, M., Schumacher Jr., H.R., 2003. Synovial fluid features and their relations to osteoarthritis severity: new findings from sequential studies. Osteoarthritis Cartilage 11 (1), 50-54.

Narama, I., Masuoka-Nishiyama, M., Matsuura, T., Ozaki, K., Nagatani, M., Morishima, T., 1996. Morphogenesis of degenerative changes predisposing dogs to rupture of the cranial cruciate ligament. J. Vet. Med. Sci. 58 (11), 1091-1097.

Niebauer, G.W., Menzel, E.J., 1982. Immunological changes in canine cruciate ligament rupture. Res. Vet. Sci. 32, 235-241.

Niebauer, G.W., Wolf, B., Bashey, R.I., Newton, C.D., 1987. Antibodies to canine collagen types I and II in dogs with spontaneous cruciate ligament rupture and osteoarthritis. Arthritis Rheum. 30, 319-327.

Oddie, G.W., Schenk, G., Angel, N.Z., Walsch, N., Guddat, L.W., De Jersey, J., Cassady, A.I., Hamilton, S.E., Hume, D.A., 2000. Structure, function, and regulation of tartrate-resistant acid phosphatase. Bone 27 (5), 575-584.

Ogura, N., Tobe, M., Sakamaki, H., Nagura, H., Abiko, Y., Kondoh, T., 2005. Tumor necrosis factor-alpha increases chemokine gene expression and production in synovial fibroblasts from human temporomandibular joint. J. Oral Pathol. Med. 34 (6), 357-363.

Osborne, A.C., Carter, S.D., May, S.A., Bennett, D., 1995. Anticollagen antibodies and immune complexes in equine joint diseases. Vet. Immunol. Immunopathol. 45 (1), 19-30.

Overall, C.M., Wrana, J.L., Sodek, J., 1989. Independent regulation of collagenase, $72-\mathrm{kDa}$ progelatinase, and metalloendoproteinase inhibitor expression in human fibroblasts by transforming growth factor-beta. J. Biol. Chem. 264, 1860-1869.

Park, S.-H., Min, D.-J., Cho, M.-L., Kim, W.-U., Youn, J., Park, W., Cho, C.-S., Kim, H.-Y., 2001. Shift toward T helper 1 cytokines by type II collagen-reactive $\mathrm{T}$ cells in patients with rheumatoid arthritis. Rheum. Dis. Clin. North Am. 19 (3), 545-568.

Peichl, P., Ceska, M., Broell, H., Effenberger, F., Lindley, I.J., 1992. Human neutrophil activating peptide/interleukin 8 acts as an autoantigen in rheumatoid arthritis. Ann. Rheum. Dis. 51, 19-22.

Pelletier, J.P., DiBattista, J.A., Roughley, P., McCollum, R., MartelPelletier, J., 1993a. Cytokines and inflammation in cartilage degradation. Rheum. Dis. Clin. North Am. 19, 545-568.

Pelletier, J.P., Faure, M.P., DiBattista, J.A., Wilhelm, S., Visco, D., Martel-Pelletier, J., 1993b. Coordinate synthesis of stromelysin, interleukin-1, and oncogene proteins in experimental osteoarthritis. An immunohistochemical study. Am. J. Pathol. 142, 95-105.

Pelletier, J.P., Martel-Pelletier, J., Howell, D.S., 1996. Ethiopathogenesis of Osteoarthritis. In: McCarty, D.J., Koopman, W.J. (Eds.), Arthritis And Allied Conditions: A Textbook of Rheumatology. Lea \& Febiger, Philadelphia.

Petrovic-Rackov, L., Pejnovic, N., 2006. Clinical significance of IL18, IL-15, IL-12 and TNF-alpha measurement in rheumatoid arthritis. Clin. Rheumatol. 25 (4), 448-452.
Pond, M.J., Campbell, J.R., 1972. The canine stifle joint. I. Rupture of the anterior cruciate ligament. An assessment of conservative and surgical treatment. J. Small Anim. Pract. 13, 1-10.

Postlethwaite, A.E., Keski-Oja, J., Moses, H.L., Kang, A.H., 1987. Stimulation of the chemotactic migration of human fibroblasts by transforming growth factor beta. J. Exp. Med. 165, 251-256.

Puliti, M., von Hunolstein, C., Bistoni, F., Mosci, P., Orefici, G., Tissi, L., 2000. Influence of interferon-gamma administration on the severity of experimental group B streptococcal arthritis. Arthritis Rheum. 43, 2060-2065.

Rayward, R.M., Thomson, D.G., Davies, J.V., Innes, J.F., Whitelock, R.G., 2004. Progression of osteoarthritis following TPLO surgery: a prospective radiographic study of 40 dogs. J. Small Anim. Pract. 45, 92-97.

Raza, K., Falciani, F., Curnow, S.J., Ross, E.J., Lee, C.Y., Akbar, A.N., Lord, J.M., Gordon, C., Buckley, C.D., Salmon, M., 2005. Early rheumatoid arthritis is characterized by a distinct and transient synovial fluid cytokine profile of $\mathrm{T}$ cell and stromal cell origin. Arthritis Res. Ther. 7 (4), R784-R795.

Read, R.A., Robins, G.M., 1982. Deformity of the proximal tibia in dogs. Vet Rec. 111, 295-298.

Rook, G., 1993. Cell-mediated immune reactions. In: Roitt, I., Brostoff, J., Male, D. (Eds.), Immunology. Mosby, St-Louis, pp. 8.3-8.16.

Sadouk, M., Pelletier, J.P., Tardif, G., Kiansa, K., Cloutier, J.M., Martel-Pelletier, J., 1995. Human synovial fibroblasts coexpress interleukin-1 receptor type I and type II mRNA: the increased level of the interleukin-1 receptor in osteoarthritic cells is related to an increased level of the type I receptor. Lab Invest. 73, 347-355.

Saito, I., Koshino, T., Nakashima, K., Uesugi, M., Saito, T., 2002. Increased cellular infiltrate in inflammatory synovia of osteoarthritic knees. Osteoarthritis Cartilage 10 (2), 156-162.

Salinardi, B.J., Roush, J.K., Schermerhorn, T., Mitchell, K.E., 2006. Matrix metalloproteinase and tissue inhibitor of metalloproteinase in serum and synovial fluid of osteoartritic dogs. Vet. Comp. Orthop. Traumatol. 19, 49-55.

Schultze, K.H., Kalden, J.R., 2001. The balance of Th1/Th2 cytokines in rheumatoid arthritis. Best Pract. Res. Clin. Rheum. 15, 677-691.

Sebbag, M., Parry, S.L., Brennan, F.M., Feldmann, M., 1997. Cytokine stimulation of $\mathrm{T}$ lymphocytes regulates their capacity to induce monocyte production of tumor necrosis factor-alpha, but not interleukin-10: possible relevance to pathophysiology of rheumatoid arthritis. Eur. J. Immunol. 27 (3), 624-632.

Seitz, M., Loetscher, P., Dewald, B., Towlin, H., Ceska, M., Bagglioni, M., 1994. Productions of interleukin-1 receptor antagonist, inflammatory chemotactic proteins, and prostaglandine $\mathrm{E}$ by rheumatoid and osteoarthritis synoviocytes. Regulation by IFN- $\gamma$ and Il-4. J. Immunol. 152, 2062-2086.

Shinmei, M., Okada, Y., Masuda, K., Naramatsu, M., Kikuchi, T., Harigai, M., Shimomura, Y., 1990. The mechanism of cartilage degradation in osteoarthritic joints. Semin. Arthritis Rheum. 19, $16-20$.

Shinmei, M., Masuda, K., Kikuchi, T., Shimomura, Y., Okada, Y., 1991. Production of cytokines by chondrocytes and its role in proteoglycan degradation. J. Rheumatol. 18, 89-91.

Slocum, B., Slocum, T.D., 1993. Tibial plateau leveling osteotomy for repair of cranial cruciate ligament rupture in the canine. Vet. Clin. North Am. Small Anim. Pract. 23, 777-802. 
Smiley, J.D., Sachs, C., Ziff, M., 1968. In vitro synthesis of immunoglobulin by rheumatoid synovial membrane. J. Clin. Invest. 47 (3), 624-632.

Spreng, D., Sigrist, N., Busato, A., von Rechenberg, Schawalder, P., 1999. Stromelysin activity in canine cranial cruciate ligament rupture. Vet. Comp. Othop. Traumatol. 12, 159-165.

Strande, A., 1967. Repair of the ruptured cranial cruciate ligament in the dog. PhD thesis. University of Oslo.

Stuart, J.M., Huffstutter, E.H., Townes, A.S., Kang, A.H., 1983. Incidence and specificity of antibodies to types I, II, III, IV, and $\mathrm{V}$ collagen in rheumatoid arthritis and other rheumatic diseases as measured by $125 \mathrm{I}$-radioimmunoassay. Arthritis Rheum. 26 (7), 832-840.

Sugiyama, E., Kuroda, A., Taki, H., Ikemoto, M., Hori, T., Yamashita, N., Maruyama, M., Kobayashi, M., 1995. Interleukin 10 cooperates with interleukin 4 to suppress inflammatory cytokine production by freshly prepared adherent rheumatoid synovial cells. J. Rheumatol. 22, 2020-2026.

Sukedai, M., Tominaga, K., Habu, M., Matsukawa, A., Nishihara, T., Fukuda, J., 2004. Involvement of tumor necrosis factor-alpha and interleukin-8 in antigen-induced arthritis of the rabbit temporomandibular joint. J. Oral Pathol. Med. 33 (2), 102-110.

Symons, J.A., Eastgate, J.A., Duff, G.W., 1991. Purification and characterization of a novel soluble for interleukin-1. J. Exp. Med. 174, 1251-1254.

Symons, J.A., Wong, W.L., Palladino, M.A., Duff, G.W., 1992. Interleukin- 8 in rheumatoid and osteoarthritis. Scan. J. Rheumatol. 21, 92-94.

Tchetverikov, I., Lohmander, L.S., Verzijl, N., Huizinga, T.W., TeKoppele, J.M., Hanemaaijer, R., DeGroot, J., 2005. MMP protein and activity levels in synovial fluid from patients with joint injury, inflammatory arthritis, and osteoarthritis. Ann. Rheum. Dis. 64 (5), 694-698.

Thomas, M.L., 1989. The leukocyte common antigen family. Ann. Rev. Immun. 12, 85-116.

Tipton, C.M., James, S.L., Mergner, W., Tcheng, T.K., 1970. Influence of exercise on strength of medial collateral knee ligaments of dogs. Am. J. Physiol. 218 (3), 894-902.

Tirgari, M., 1977. Changes in the canine stifle joint following rupture of the anterior cruciate ligament. J. Small Anim. Pract. 19, 17-26.

Tracey, K.J., 1994. Tumour necrosis factor-alpha. In: Thomson, A. (Ed.), The Cytokine Handbook. Academic Press, London, pp. 289-304.

Trentham, D.E., Townes, A.S., Kang, A.H., 1977. Aotoimmunity to type II collagen: an experimental model of arthritis. J. Exp. Med. $146,857-868$

Tsuboi, H., Matsui, Y., Hayashida, K., Yamane, S., Maeda-Tanimura, M., Nampei, A., Hashimoto, J., Suzuki, R., Yoshikawa, H., Ochi, T., 2003. Tartrate resistant acid phosphatase (TRAP) positive cells in rheumatoid synovium may induce the destruction of articular cartilage. Ann. Rheum. Dis. 62 (3), 196-203.

Tyler, J.A., 1989. Insulin-like growth factor 1 can decrease degradation and promote synthesis of proteoglycan in cartilage exposed to cytokines. Biochem. J. 260, 543-548.

Uria, J.A., Jimenez, M.G., Balbin, M., Freije, J.M., Lopez-Otin, C., 1998. Differential effects of transforming growth factor-beta on the expression of collagenase- 1 and collagenase- 3 in human fibroblasts. J. Biol. Chem. 264, 1860-1869.
Van Damme, J., 1994. Interleukin-8 and related chemotactic cytokines. In: Thomson, A. (Ed.), The Cytokine Handbook. Academic Press, London, pp. 185-208.

van Lent, P.L., Blom, A.B., van der Kraan, P., Holthuysen, A.E., Vitters, E., van Rooijen, N., Smeets, R.L., Nabbe, K.C., van den Berg, W.B., 2004. Crucial role of synovial lining macrophages in the promotion of transforming growth factor beta-mediated osteophyte formation. Arthritis Rheum. 50, 103-111.

van Sickle, D.C., Delleman, D.H., Brown, E.M., 1993. Connective and supportive tissues. In: Dellmann, H., van Sickle, D.C., Brown, E.M. (Eds.), Textbook of Veterinary Histology. Lea \& Febiger, Philadelphia, pp. 29-53.

Vasseur, P.B., Pool, R.R., Arnoczky, S.P., Lau, R.E., 1985. Correlative biomechanical and histologic study of the cranial cruciate ligament in dogs. Am. J. Vet. Res. 46, 1842-1854.

Venn, G., Nietfeld, J.J., Duits, A.J., Brennan, F.M., Arner, E., Covington, M., Billingham, M.E., Hardingham, T.E., 1993. Elevated synovial fluid levels of interleukin-6 and tumor necrosis factor associated with early experimental canine osteoarthritis. Arthritis Rheum. 36, 819-826.

Veys, E.M., Menkes, C.J., Emery, P., 1997. A randomized, doubleblind study comparing twenty-four-week treatment with recombinant interferon-gamma versus placebo in the treatment of rheumatoid arthritis. Arthritis Rheum. 40, 62-68.

Volk, S.W., Kapatkin, A.S., Haskins, M.E., Walton, R.M., D’Angelo, M., 2003. Gelatinase activity in synovial fluid and synovium obtained from healthy and osteoarthritic joints of dogs. Am. J. Vet. Res. 64, 1225-1233.

Wahl, S.M., McCartney-Francis, N., Mergenhagen, S.E., 1989. Inflammatory and immunomodulatory roles of TGF-beta. Immunol. Today $10,258-261$.

Wahl, S.M., Allen, J.B., Costa, G.L., Wong, H.L., Dasch, J.R., 1993. Reversal of acute and chronic synovial inflammation by antitransforming growth factor beta. J. Exp. Med. 177 (1), 225-230.

Whellams, E.J., Maile, L.A., Fernihough, J.K., Billingham, M.E., Holly, J.M., 2000. Alterations in insulin-like growth factor binding protein-3 proteolysis and complex formation in the arthritic joint. J. Endocrinol. 165, 545-556.

Wood, D.D., Ihrie, E.J., Hamerman, D., 1985. Release of interleukin-1 from human synovial tissue in vitro. Arthritis Rheum. 28, 853-862.

Xie, D.L., Meyers, R., Homandberg, G.A., 1992. Fibronectin fragments in osteoarthritic synovial fluid. J. Rheumatol. 19, $1448-1452$.

Yasuda, K., Tomita, F., Yamazaki, S., Minami, A., Tohyama, H., 2004. The effect of growth factors on biomechanical properties of the bone-patellar tendon-bone graft after anterior cruciate ligament reconstruction: a canine model study. Am. J. Sports Med. 32, 870-880.

Yuan, G.-H., Masuko Hongo, K., Kato, T., Nishioka, K., 2003. Immunologic intervention in the pathogenesis of osteoarthritis. Arthritis Rheum. 48, 602-611.

Zahm, H., 1965. Die ligament decussate im gesunden und arthrotischen Kniegelenk des Hundes. 10, 38-47.

Zhou, D., Lee, H.S., Villarreal, F., Teng, A., Lu, E., Reynolds, S., Qin, C., Smith, J., Sung, K.L., 2005. Differential MMP-2 activity of ligament cells under mechanical stretch injury: an in vitro study on human ACL and MCL fibroblasts. J. Orthop. Res. 23, 949-957. 